\title{
Effect of Prostanoids on Human Platelet Function: An Overview
}

\author{
Steffen Braune, Jan-Heiner Küpper and Friedrich Jung * \\ Institute of Biotechnology, Molecular Cell Biology, Brandenburg University of Technology, \\ 01968 Senftenberg, Germany; steffen.braune@b-tu.de (S.B.); Jan-Heiner.Kuepper@b-tu.de (J.-H.K.) \\ * Correspondence: Friedrich.Jung@b-tu.de
}

Received: 23 October 2020; Accepted: 23 November 2020; Published: 27 November 2020

\begin{abstract}
Prostanoids are bioactive lipid mediators and take part in many physiological and pathophysiological processes in practically every organ, tissue and cell, including the vascular, renal, gastrointestinal and reproductive systems. In this review, we focus on their influence on platelets, which are key elements in thrombosis and hemostasis. The function of platelets is influenced by mediators in the blood and the vascular wall. Activated platelets aggregate and release bioactive substances, thereby activating further neighbored platelets, which finally can lead to the formation of thrombi. Prostanoids regulate the function of blood platelets by both activating or inhibiting and so are involved in hemostasis. Each prostanoid has a unique activity profile and, thus, a specific profile of action. This article reviews the effects of the following prostanoids: prostaglandin- $\mathrm{D}_{2}\left(\mathrm{PGD}_{2}\right)$, prostaglandin- $\mathrm{E}_{1},-\mathrm{E}_{2}$ and $\mathrm{E}_{3}\left(\mathrm{PGE}_{1}, \mathrm{PGE}_{2}, \mathrm{PGE}_{3}\right)$, prostaglandin $\mathrm{F}_{2 \alpha}\left(\mathrm{PGF}_{2 \alpha}\right)$, prostacyclin $\left(\mathrm{PGI}_{2}\right)$ and thromboxane- $\mathrm{A}_{2}\left(\mathrm{TXA}_{2}\right)$ on platelet activation and aggregation via their respective receptors.
\end{abstract}

Keywords: prostacyclin; thromboxane; prostaglandin; platelets

\section{Introduction}

Hemostasis is a complex process that requires the interplay of multiple physiological pathways. Cellular and molecular mechanisms interact to stop bleedings of injured blood vessels or to seal denuded sub-endothelium with localized clot formation (Figure 1). Once vascular integrity is restored, clot formation stops and normal hemostasis is reinstated. Thrombotic imbalance may occur in patients with atherosclerotic diseases and activated platelets. The latter expose a plethora of receptors (e.g., CD62P and PAC1) and phosphatidylserine on their plasma membrane, resulting in the recruitment of circulating platelets (thrombus formation) as well as the binding and activation of the prothrombinase complex (thrombin formation) [1]. Activated platelets further mediate thrombotic processes and hemostasis by releasing bioactive substances such as growth factors, chemokines, $\mathrm{Ca}^{2+}$, adenosine diphosphate (ADP/ATP) as well as phospholipids [2,3]. Accordingly, hyperreactive platelets play a critical role in several pathological conditions such as atherosclerosis [4-6], stroke or myocardial infarction [7-10], but also after the implantation of cardiovascular implants [11-13]. Despite the successful application of anti-platelet therapies, it remains challenging to sufficiently impair the hyperreactivity of platelets, while balancing medication-induced risks for major bleedings. Here, we review the present literature data available on the influence of prostanoids on platelet function and their therapeutic potential in cardiovascular diseases. 


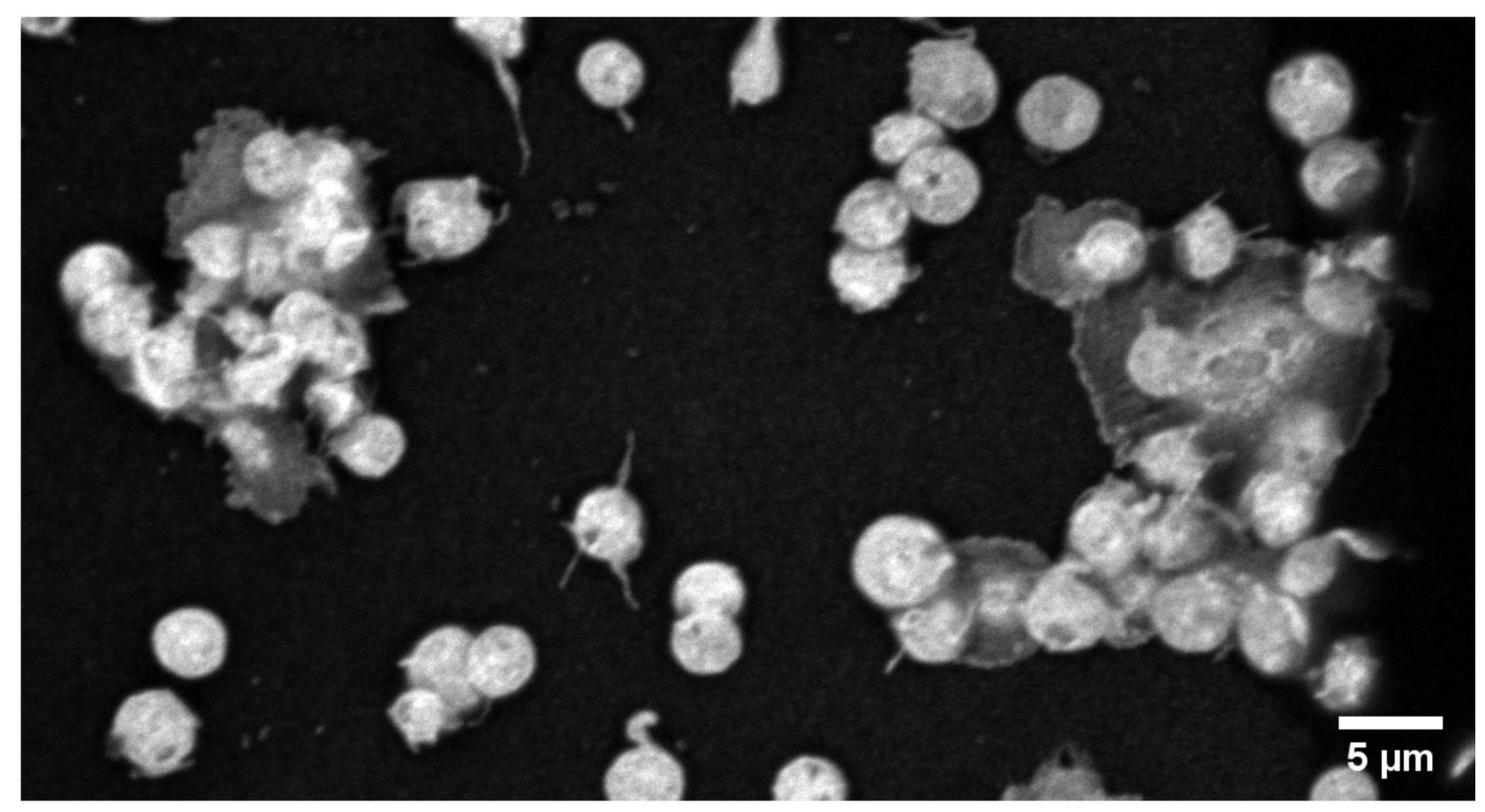

Figure 1. Morphology of activated platelets and platelet-aggregates adherent on collagen after $60 \mathrm{~min}$ treatment with platelet rich plasma. Adherent platelets were treated with a $2 \%$ glutardialdehyde solution for visualizing the platelet body unspecifically (Glutardialdehyde Induced Fluorescence Staining). Microscopy was conducted at 100-fold primary magnification with a ZEISS LSM800 in the high resolution AIRYSCAN-mode.

\section{Generation of Prostanoids in Platelets}

Following the primary activation by, e.g., collagen and thrombin, bioactive lipids are formed in the platelet, which support consolidation of the activation process [14]. Most of these substances originate from free fatty acids such as arachidonic acid, the most common fatty acid in the platelet phospholipid membrane (Figure 2). Prostanoids are a family of these lipid mediators and consist of prostaglandins, prostacyclins and thromboxanes. The prostanoids are not stored in a reservoir but are synthesized de novo and released into the extracellular space when platelets are activated and exogenous free arachidonate is supplied [15]. The major site for prostanoid biosynthesis in the human platelet is the dense tubular system (DTS) $[16,17]$. This endomembrane system forms a residual smooth endoplasmatic reticulum (ER) and originates from the rough ER of the platelet shedding megakaryocytes. The elongated and irregularly formed organelle is located near the plasma membrane and microtubules. The DTS stores calcium as well as thromboxane synthetase, prostaglandin $\mathrm{G} / \mathrm{H}$ synthase and cyclooxygenase (COX) [18]. These enzymes can transfer C-20 polyunsaturated fatty acids-mainly dihomo-gamma-linoleic (20:3n-6), arachidonic (20:4n-6), and eicosapentaenoic (20:5n-3) acids-into their oxidized active form, which are then released into the extra-platelet space.

Particularly, COX-1 is the dominant-but not exclusive-source of prostanoids in platelets. COX-2 is located in the vasculature induced by cytokines or shear stress and is the more important source of prostanoid formation in inflammation. However, both enzymes contribute to the generation of autoregulatory and homeostatic prostanoids. Five primary prostanoids are described today: prostaglandin- $\mathrm{D}_{2}\left(\mathrm{PGD}_{2}\right)$, prostaglandin- $\mathrm{E}_{1}\left(\mathrm{PGE}_{1}\right)$, prostaglandin- $\mathrm{F}_{2 \alpha}\left(\mathrm{PGF}_{2 \alpha}\right)$, prostacyclin (prostaglandin- $\left.\mathrm{I}_{2}\right)$, and thromboxane- $\mathrm{A}_{2}\left(\mathrm{TX}_{2}\right)$. Each of them signals through a distinct transmembrane guanosine-5'-triphosphate-(GTP) binding protein coupled receptor. 


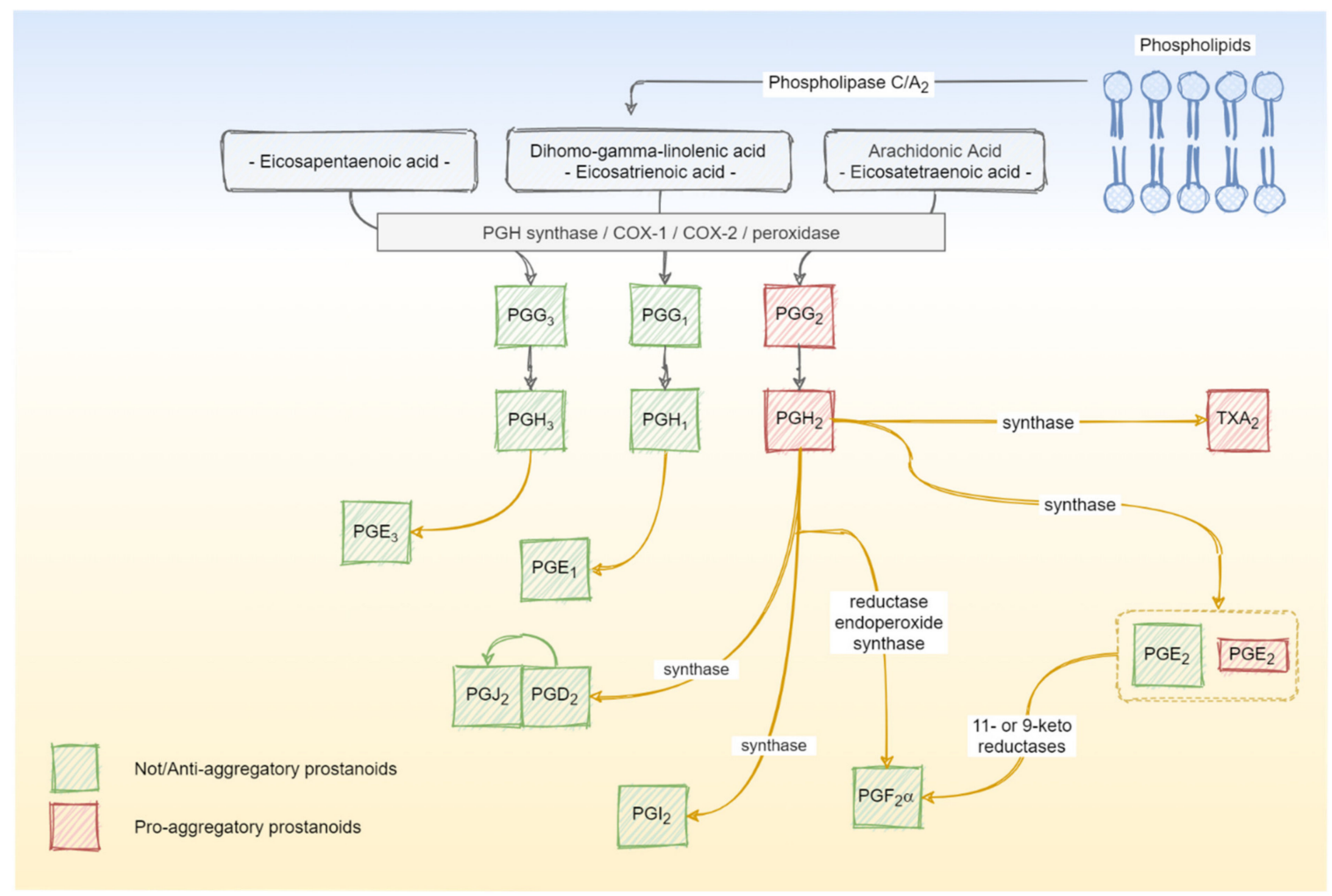

Figure 2. Overview of the major sources and biosynthesis routes of pro- and anti-platelet aggregatory prostanoids in the dense tubular system of human platelets.

\section{Prostanoid Receptors}

Prostaglandins and thromboxane bind to cognate receptors: Prostaglandin- $\mathrm{D}_{2}$ receptor $\left(\mathrm{DP}_{1}\right)$, Prostaglandin- $\mathrm{E}_{2}$ receptor (EP), Prostaglandin $-\mathrm{F}_{2}$ receptor $(\mathrm{FP})$, Prostaglandin- $\mathrm{I}_{2}$ receptor (IP) and $\mathrm{TXA}_{2}$ receptor $(\mathrm{TP})[19,20]$. There are four subtypes of prostaglandin- $\mathrm{E}_{2}$ receptors: EP1, EP2, EP3 and EP4 [21]. In these four subtypes, EP3 is unique and has several isoforms derived from alternative splicing $[22,23]$.

In addition to these eight types and subtypes, a further receptor for prostaglandin- $\mathrm{D}_{2}$ exists: the chemoattractant receptor-homologous molecule expressed on T-helper type 2 cells $\left(\mathrm{DP}_{2}, \mathrm{CRTH}_{2}\right)$. However, it has no significant sequence homology of amino acids with the prostaglandin- $\mathrm{D}_{2}$ receptor $\mathrm{DP}_{1}$ and other prostanoid receptors [24]. Via these receptors, prostanoids exert a variety of actions in various tissues and cells [25]. The regulation of platelet function is one of their most studied actions [26,27].

Several prostanoid receptors are expressed in human platelets: $\mathrm{DP}_{1}$ along with EP2, EP3, EP4, IP and TP $[28,29]$. Five with six subtypes are established so far. Table 1 summarizes these receptors, their G-protein and the respective signaling pathways. The following receptors regulate adenylyl cyclase (AC): IP, DP1, EP2, EP3, EP4, TP, DP2. While inhibition of AC results in a decrease in cyclic adenosine monophosphate (cAMP), its activation leads to an increase of this secondary messenger [30,31]. Further second messenger molecules are formed upon activation of phosphatidylinositol ${ }_{3}$-kinase $\left(\mathrm{PI}_{3} \mathrm{~K}\right)$ by EP4: PI 3 -phosphate, $\mathrm{PI}_{(3,4)}$-bisphosphate, and PI $(3,4,5)$-trisphosphate [32]. Activated phospholipase-C (PLC) induces the generation of diacylglycerol (DAG) and inositol trisphosphate (IP3) secondary messengers [33]. Both are responsible for raising cytosolic $\mathrm{Ca}^{2+}$ levels and, thus, calcium-dependent pathways of platelet activation. Also, protein kinase-C (PKC) secondary messengers are activated through IP3 and DAG formation. Activation of p38 mitogen-activated protein kinases (p38 MAPK), the extracellular signal-regulated kinases (ERK), as well as the cAMP-response element-binding 
protein (CREB) leads to phosphorylation (influence activity) of key proteins that govern platelet function $[34,35]$.

Table 1. Prostanoid, receptor (sub) types and signaling pathways.

\begin{tabular}{|c|c|c|c|c|c|c|c|c|c|c|c|}
\hline Prostanoid & & $\mathrm{PGD}_{2}$ & & $\mathrm{PGE}_{1}$ & $\mathrm{PGE}_{2}$ & & & $\mathrm{PGE}_{3}$ & $\mathrm{PGF}_{2 \alpha}$ & $\mathbf{P G I}_{2}$ & $\mathrm{TXA}_{2}$ \\
\hline Receptor & & $\mathrm{DP}$ & & IP, EP & $\mathrm{EP}$ & & & & FP & $\mathrm{IP}$ & $\mathrm{TP}$ \\
\hline & Subtype & $\mathrm{DP}_{1}$ & $\begin{array}{c}\mathrm{DP}_{2} \\
\mathrm{CRTH}_{2}\end{array}$ & & (EP1) & EP2 & EP3 & EP4 & & & $\mathrm{TP}_{\mathrm{a}}$ \\
\hline G-protein & Linkage & $\mathrm{G}_{\mathrm{s}}$ & $\mathrm{G}_{\mathrm{i}}$ & $\mathrm{G}_{\mathrm{s}}$ & $\mathrm{G}_{\mathrm{q}}$ & $\mathrm{G}_{\mathrm{s}}$ & $\mathrm{G}_{\mathrm{i}}$ & $\mathrm{G}_{\mathrm{s}}$ & $\mathrm{G}_{\mathrm{q}}$ & $\mathrm{G}_{\mathrm{s}}$ & $\mathrm{G}_{\mathrm{q}}$ \\
\hline \multirow{13}{*}{$\begin{array}{l}\text { Signaling } \\
\text { pathway }\end{array}$} & $\mathrm{AC}$ & $\uparrow$ & $\downarrow$ & $\uparrow$ & & $\uparrow$ & $\downarrow$ & $\uparrow$ & & $\uparrow$ & \\
\hline & $\mathrm{Ca}^{2+}$ & $\uparrow$ & $\uparrow$ & & $\uparrow$ & & $\uparrow$ & & $\uparrow$ & & $\uparrow$ \\
\hline & cAMP & $\uparrow$ & $\downarrow$ & $\uparrow$ & & $\uparrow$ & $\downarrow$ & $\uparrow$ & & $\uparrow$ & \\
\hline & CREB & & & & $\uparrow$ & & & $\uparrow$ & & & \\
\hline & ERK & & & & $\uparrow$ & & & $\uparrow$ & & & \\
\hline & GSK3 & & & & & $\uparrow$ & & & & & \\
\hline & IP3 & & & & $\uparrow$ & & $\uparrow$ & & $\uparrow$ & & $\uparrow$ \\
\hline & $\mathrm{PI}_{3} \mathrm{~K}$ & & & & & & & $\uparrow$ & & & \\
\hline & p38 MAPK & & & & $\uparrow$ & & & $\uparrow$ & & & \\
\hline & PLC & & & & $\uparrow$ & & $\uparrow$ & & $\uparrow$ & & $\uparrow$ \\
\hline & PKA & & & & & & & $\uparrow$ & & $\uparrow$ & \\
\hline & PKB (AKT) & & & & & & & $\uparrow$ & & & \\
\hline & PKC & & & & $\uparrow$ & & & & $\uparrow$ & & \\
\hline
\end{tabular}

$\uparrow:$ activation, increase, stimulation; $\downarrow$ : inhibition, decrease. AC: adenylyl cyclase. Ca2+: calcium ion. cAMP: cyclic adenosine monophosphate. CREB: cAMP-response element-binding protein. ERK: extracellular signal-regulated kinases. GSK3: glycogen synthase kinase 3. IP3: inositol trisphosphate. PI3K: phosphatidylinositol 3-kinase. p38 MAPK: p38 mitogen-activated protein kinases. PLC: phospholipase-C. PKA: protein kinase A/cAMP-dependent protein kinase. PKB (AKT): activation of protein kinase-B. PKC: protein kinase-C. ( ): not shown in human platelets. Stimulatory effects of prostanoids on platelet aggregation.

In the following paragraphs, an overview about stimulatory and inhibitory influences of prostanoids on platelet activation are depicted.

\subsection{Thromboxane $A_{2}\left(T X A_{2}\right)$}

The main prostanoid produced by activated platelets and endothelial cells is TXA 2 . Beyond its generation in platelets, it is also released by endothelial cells and has prothrombotic properties [36-39]. The prothrombotic molecule is very unstable in aqueous solutions since it is hydrolyzed within about $30 \mathrm{~s}$ to the biologically inactive thromboxane- $\mathrm{B}_{2}\left(\mathrm{TXB}_{2}\right.$, half-life time 5-7 min, plasma levels: 2 to $285 \mathrm{pg} / \mathrm{mL}$ ) [40-43]. Due to its short half-life, it primarily functions as an autocrine or paracrine mediator in the tissues adjacent to its site of generation. Beyond its influence on platelets, it acts as a vasoconstrictive, and mediates angiogenesis and inflammatory processes [44].

$\mathrm{TXA}_{2}$ binds to the $\mathrm{TP}_{\mathrm{a}}$ receptor, which results in $\mathrm{TXA}_{2}$-induced platelet-shape change, inside-out activation of integrins, and degranulation (Figure 3) [45]. The receptor couples to the PLC stimulatory G-protein $\left(\mathrm{G}_{\mathrm{q}}\right)$ and activates it. This leads to the elevation of intracellular $\mathrm{Ca}^{2+}$ concentrations, released from the DTS. 


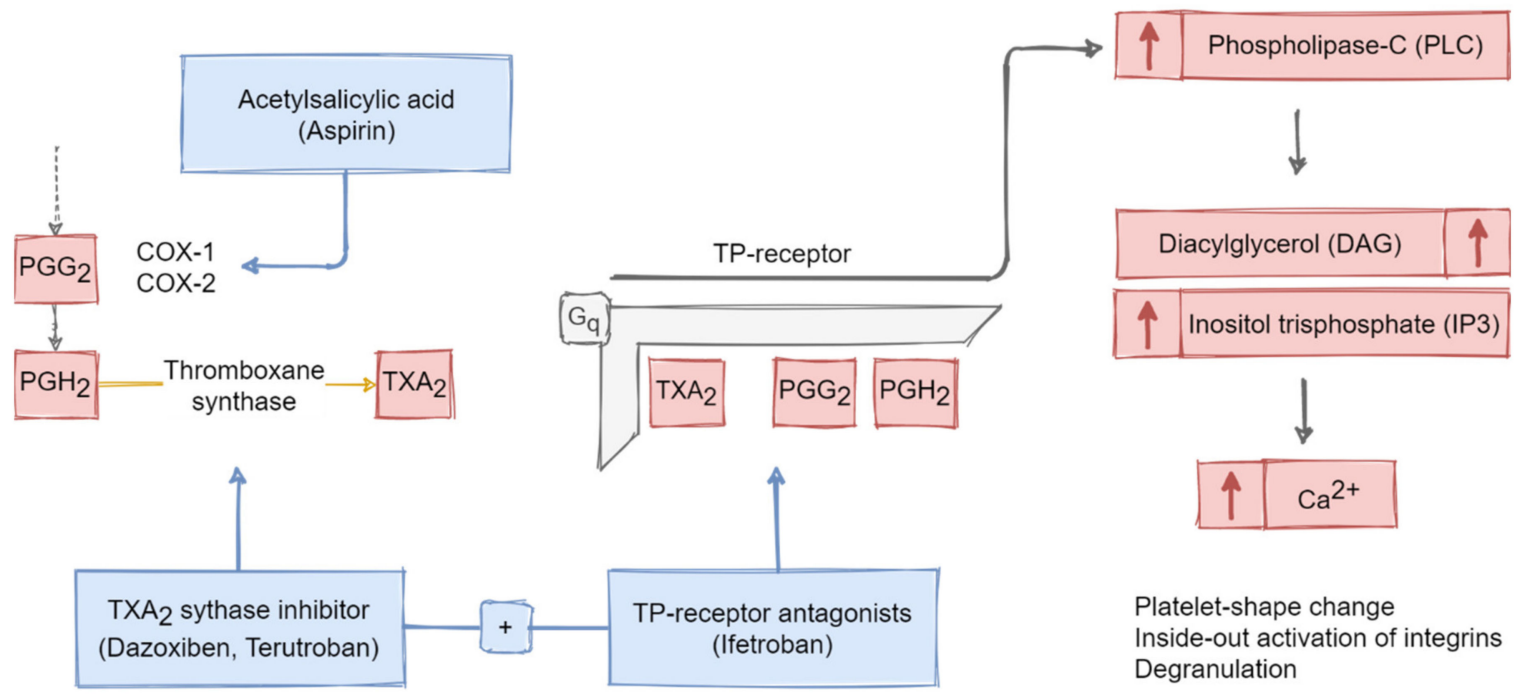

Figure 3. Schematic overview of the molecular pathways responsible for $\mathrm{TXA}_{2}$ - as well as its precursors $\mathrm{PGG}_{2}$ - and $\mathrm{PGH}_{2}$-mediated induction of platelet activation via the TP-receptor. Activating processes comprise downregulation of AC and upregulation of PLC. These processes lead to the elevation of calcium mobilization and secretion through DAG and IP3 activation. Therapeutic options include blockage of the COX-mediated synthesis of $\mathrm{TXA}_{2}$ as well as the combined administration of TP-receptor antagonists and TXA 2 synthase inhibitors (red arrows in boxes pointing upwards indicate activation or increase of the respective substance).

In human platelets, a stable TXA 2 mimetic induced platelet aggregation and the release of granule contents from platelets [46]. This was followed by an amplification loop, which led to further platelet activation, aggregation and TXA $\mathrm{A}_{2}$ formation [47]. Platelets express the TP receptor constitutively and generate $\mathrm{TXA}_{2}$ when activated with collagen, adenosine diphosphate (ADP), epinephrine, thrombin or TXA 2 itself. Whereas elevated levels of TXA ${ }_{2}$ are associated with thrombotic and ischemic events, deficiencies can result in bleeding [48-50]. Thus, $\mathrm{TXA}_{2}$ plays an important role as a positive feedback regulator in the regulation of platelet function.

Therapeutically, acetylsalicylic acid (Aspirin) is classically applied to reduce the risk for acute coronary events through inhibition of the COX-mediated generation of $\mathrm{TXA}_{2}$ and prostaglandin endoperoxides.

Beyond its primary agonist $\mathrm{TXA}_{2}$, the TP receptor is also available for its metabolic precursors prostaglandin $\mathrm{G}_{2}\left(\mathrm{PGG}_{2}\right)$ and prostaglandin $\mathrm{H}_{2}\left(\mathrm{PGH}_{2}\right)$ [51]. Binding of both to TP showed similar platelet responses compared to $\mathrm{TXA}_{2}$. These findings became particularly important for the clinical application of $\mathrm{TXA}_{2}$ synthase inhibitors (e.g., Dazoxiben). Despite the fact that the metabolites did reduce $\mathrm{TXA}_{2}$ production and stimulated the generation of anti-aggregatory $\mathrm{PGE}_{2}, \mathrm{PGD}_{2}, \mathrm{PGI}_{2}$ and $\mathrm{PGF}_{2 \alpha}$, they led to an accumulation of the pro-aggregatory precursors mentioned above [52,53].

Limitations of this approach could be reduced through the combined administration of TXA 2 synthase inhibitors and TP receptor antagonists (e.g., Terutroban and Ifetroban) [54,55]. The latter were shown to reduce $\mathrm{TXA}_{2}$ (or precursors)-induced platelet aggregation and shape change in patients in a comparable manner to Aspirin [56,57].

\subsection{Prostaglandin- $E_{2}\left(P G E_{2}\right.$, Low Concentrations)}

Prostaglandin- $\mathrm{E}_{2}$ is a lipid, arachidonic acid-derived, prostaglandin hormone. It is a product of the arachidonic acid metabolism in varying cells, including smooth muscle cells, colon cells, fibroblasts, platelets and macrophages, and plays an important role in inflammation as well as cancer [58-60].

In the human microvasculature, $\mathrm{PGE}_{2}$ is the main prostanoid secreted by endothelial cells [61] and can influence the vascular tone and angiogenesis [62]. In atherosclerotic plaques, activated 
macrophages contribute to elevation of $\mathrm{PGE}_{2}$ levels, which triggers platelet activation during plaque growth and upon rupture [63,64].

In vivo, $\mathrm{PGE}_{2}$ is rapidly converted to an inactive metabolite (13,14-dihydro-15-keto prostaglandin- $\mathrm{E}_{2}$ ) by the prostaglandin 15-dehydrogenase pathway. Its half-life in the circulatory system is approximately $30 \mathrm{~s}$. Normal plasma levels range between 3 and $12 \mathrm{pg} / \mathrm{mL}$ [65].

Prostaglandin- $\mathrm{E}_{2}$ has been reported to have a biphasic effect on platelet activation. It potentiates, e.g., the U46619-iduced platelet aggregation, at lower concentrations (e.g., 0.1-10 $\mu \mathrm{mol} / \mathrm{L}$ ) and inhibits it at higher concentrations (e.g., $>10 \mu \mathrm{mol} / \mathrm{L}$ ) (see Figure 4) [66-69]. However, alone, it is not sufficient to induce platelet aggregation as a consequence of the strong counteracting AC stimulation of other prostanoids [70].

\section{U46619-induced platelet aggregation}

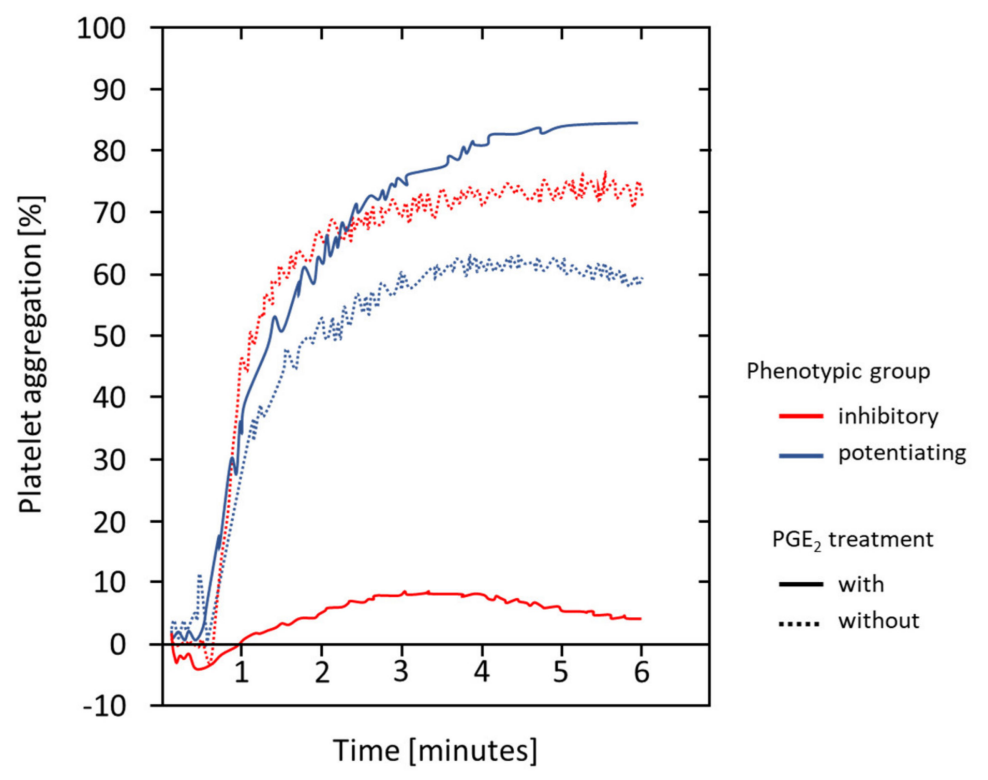

Figure 4. Representative light transmission platelet aggregation (LTA) curves showing the phenotypic differences in the response to low dosages of $\mathrm{PGE}_{2}(100 \mathrm{nmol} / \mathrm{L}, 30 \mathrm{~s} \mathrm{PGE} 2$ treatment prior activation with submaximal concentration of U46619, LTA with adjusted platelet-rich plasma with 250,000 platelets per $\mu \mathrm{L}$ ). Adapted from Friedman and colleagues [44].

It has been thought that platelet activation can be induced by cAMP inhibitory $\left(\mathrm{G}_{\mathrm{i}}\right)$ and PLC stimulatory G-protein $\left(\mathrm{G}_{\mathrm{q}}\right)$ signaling (EP3 receptor). This is counteracted by induction of the cAMP stimulatory G-protein $\left(\mathrm{G}_{\mathrm{s}}\right)$ pathway, which can inhibit platelet activation (EP4 and EP2 receptors) (Figure 5) $[63,69,71-73]$. By coupling to $G_{i}$, EP3 causes an inhibition of the AC. This leads to the above-mentioned decrease in the intra-platelet cAMP concentration and thus reduces the platelet activation threshold $[63,72,74,75]$. EP3 shares the $G_{i}$ protein pathway with the ADP-dependent P2 $\mathrm{Y}_{12}$ receptor. Through this, $\mathrm{PGE}_{2}$ can potentiate the $\mathrm{ADP}$-induced $\mathrm{AC}$ inhibition by $\mathrm{P}_{2} \mathrm{Y}_{12}$ and - to some extent-even compensate $\mathrm{P}_{2} \mathrm{Y}_{12}$ inhibition by, e.g., pharmacological antagonists [76]. Beyond this classical view, the EP3 receptor appears more complex. Six isoforms are described, which elevate cAMP and IP3 levels through $\mathrm{G}_{\mathrm{s}}, \mathrm{G}_{\mathrm{q}}$ and $\mathrm{G}_{\mathrm{z}}$ binding, differently [77-81]. 
$\mathrm{PGE}_{2}$ mediated inhibition of platelet activation

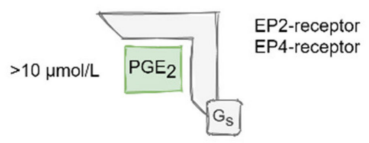
$\downarrow \downarrow$ Reduced activity or decreas

Adenyl Cyclase (AC)

$\downarrow$ ATP

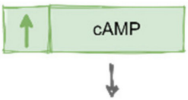

$\downarrow$
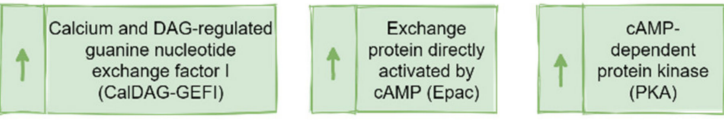

$\downarrow$

Phosphorylation

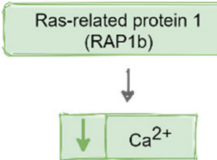

downregulation:

store-mediated $\mathrm{Ca}^{2+}$ entry

$\mathrm{Ca}^{2+}$ mobilization and secretion

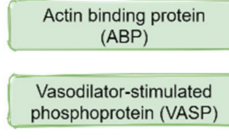

Myosin light chain

downregulation: platelet shape change cytoskeletal proteins

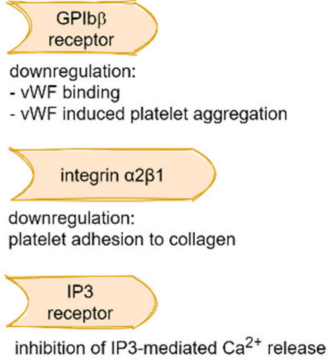

$\mathrm{PGE}_{2}$ mediated stimulation of platelet activation

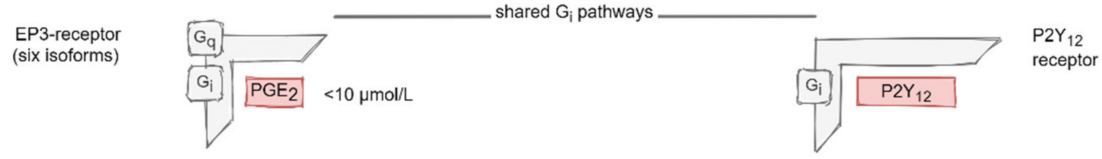

$G_{i}$

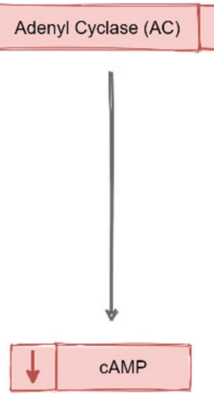

$G_{q}$

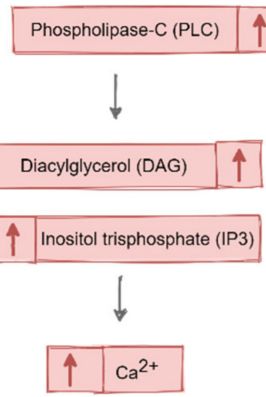

$G_{i}$

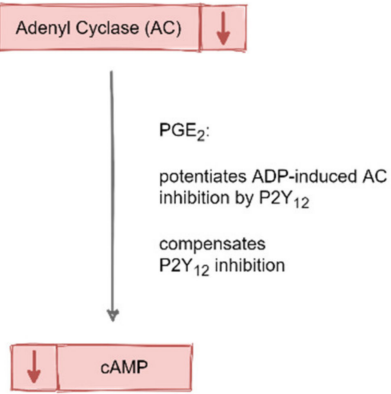

Figure 5. Schematic overview of the molecular pathways responsible for $\mathrm{PGE}_{2}$-mediated inhibition ( $\mathrm{PGE}_{2}$ concentration $>10 \mu \mathrm{mol} / \mathrm{L}$, via EP2- and EP4-receptors) and stimulation ( $\mathrm{PGE}_{2}$ concentration $<10 \mu \mathrm{mol} / \mathrm{L}$, via EP3- receptor) of platelet activation. The inhibitory pathways comprise activation of $\mathrm{AC}$ and increase of cAMP. This induces CalDAG-GEFI, EPAC and PKA signaling, which results in the phosphorylation of different proteins as well as (plasma membrane) receptors and the downregulation of calcium mobilization. Processes inducing platelet activation comprise downregulation of AC and upregulation of PLC. These processes result in the reduction of CAMP and in an elevated calcium mobilization and secretion through DAG and IP3 activation. The EP3- and P2 $\mathrm{Y}_{12}$-receptors share the $\mathrm{G}_{\mathrm{i}}$ pathway. Through this common pathway, $\mathrm{PGE}_{2}$ can potentiate the $\mathrm{P}_{2} \mathrm{Y}_{12}$-receptor-mediated and ADP-induced $\mathrm{AC}$ inhibition and, furthermore, compensate $\mathrm{P}_{2} \mathrm{Y}_{12}$ inhibition to a certain extent. 
The receptor subtypes EP4 and EP2 (both $\mathrm{G}_{\mathrm{s}}$-coupled) are regarded as inhibitory receptors, which induce AC and thus cAMP generation from ATP [82]. Elevated cAMP levels can target different pathways but majorly the cAMP-dependent protein kinase (PKA) pathway [83]. Through the binding of cAMP to the regulatory subunits of PKA, its catalytic subunits become activated and can phosphorylate several substrate proteins responsible for inhibiting platelet activation. These cAMP-dependent processes include induction of the exchange protein activated by cAMP (Epac) as well as calcium and DAG-regulated guanine nucleotide exchange factor I (CalDAG-GEFI) and, thus, Rap1 signaling [84-89]. The cAMP-mediated phosphorylation of Rap1b leads to its dissociation from the sarcoendoplasmic reticulum $\mathrm{Ca}^{2+}$-ATPases $3 \mathrm{~b}$ (SERCA $3 \mathrm{~b}$ ), which stimulates SERCA $3 \mathrm{~b}$ activity to fill the associated calcium pools in platelets [90]. This was shown to inhibit calcium mobilization and thus platelet aggregation [91,92].

Data about the recruitment of arrestins by $\mathrm{PGE}_{2}$-activated EP4, indicated that-in HEK 293 cells-EP4 signaling may also comprise cAMP-independent pathways [93]. Furthermore, anti-inflammatory signaling was shown for the EP4 receptor-associated protein (EPRAP) in human macrophages [94]. In genetically engineered HEK-293 cells, EP4 signaling has been reported to activate $\mathrm{PI}_{3} \mathrm{~K}$, leading to activation of protein kinase-B (PKB/AKT), extracellular signal-regulated kinases (ERK), as well as cAMP-independent recruitment of arrestins (PAR4-dependent pathway) [95,96]. However, it remains to be confirmed that these data are transferable to human platelets.

Phenotypic differences in the response of human platelets to low concentrations of $\mathrm{PGE}_{2}$ (e.g., 0.01-5 and $100 \mathrm{nmol} / \mathrm{L}$ ) have been shown, particularly in studies concerning the development of thromboxane synthase inhibitors $[71,97,98]$. In apparently healthy subjects, two groups were characterized showing inhibitory ( $45 \%$, also termed responders) and potentiating effects ( $55 \%$, also termed non-responders) of $\mathrm{PGE}_{2}$ on platelet aggregation (see Figure 2) [71]. Two mechanisms have been suggested, which may explain this variability: (1) subject-dependent variations in the $\mathrm{PGE}_{2}+\mathrm{TXA}_{2}$ to $\mathrm{PGD}_{2}$ ratio and (2) in the responses of the $\mathrm{AC}$ to $\mathrm{PGE}_{2}$ [99]. However, these interindividual differences diminished when platelets were treated with high concentrations of fully activating antagonists [71].

\subsection{Prostaglandin $-F_{2 \alpha}\left(P G F_{2 \alpha}\right)$}

Watanabe et al. described the formation of $\mathrm{PGF}_{2 \alpha}$ majorly as a result of the $\mathrm{PGH}_{2}$ reduction by prostaglandin reductase and endoperoxide synthase. The generation of $\mathrm{PGF}_{2 \alpha}$ through the conversion of $\mathrm{PGD}_{2}$ and $\mathrm{PGE}_{2}$ by 11- or 9-keto reductases was shown as well [100]. The half-life time of $\mathrm{PGF}_{2 \alpha}$ is less than one minute, after which it is enzymatically degraded into the more stable 15-keto-dihydro-PGF $2 \alpha$ [101]. PGF $_{2 \alpha}$ is present in most of the human tissues and majorly abundant in the reproductive system of females [102,103]. In different mice tissues but also in human endometrial adenocarcinoma (Ishikawa) cells, this prostanoid binds to the FP receptor, which couples to the $\mathrm{G}_{\mathrm{q}}$ [104-106]. Activation of FP by $\mathrm{PGF}_{2 \alpha}$ results in the IP3 and DAG formation as well as in the mobilization of $\mathrm{Ca}^{2+}[106-108]$.

Zhang et al. have provided a substantial overview of the actions of $\mathrm{PGF}_{2 \alpha}$ in different tissue cells and species [109]. Here, we want to focus on the function of $\mathrm{PGF}_{2 \alpha}$ signaling in platelets. It is noteworthy that, in the cardiovascular system, the prostanoid is mainly generated by fibroblasts in the cardiac tissue where it can induce arrhythmia, hypertrophy and fibrosis [110]. Increased levels were shown in the canine endocardium after induced cardiac ischemia and reperfusion [111]. Also increased levels of $\mathrm{PGF}_{2 \alpha}$ secretion were reported for vascular endothelial cells upon shear stress exposure [112]. In vascular smooth muscle cells, $\mathrm{PGF}_{2 \alpha}$ can induce resistance artery constriction $[110,113,114]$.

The early studies of Hung, Armstrong, and coworkers have shown that $\mathrm{PGF}_{2 \alpha}$ (and the 8-epi-metabolite, $8-15 \mu \mathrm{M}$ ) can antagonize platelet aggregation induced by $\mathrm{TXA}_{2}$ (human platelets), PAF and thrombin $[115,116]$. Interestingly, in human platelets, ADP-induced aggregation was not affected, while in murine platelets, it was enhanced in a concentration-dependent manner [116,117]. The sole administration of $\mathrm{PGF}_{2 \alpha}$ had no effect on platelet activation. Receptor blocking experiments in mice revealed that $\mathrm{PGF}_{2 \alpha}$ can decrease cAMP levels via the EP3 receptor and increase IP3 levels 
(and $\mathrm{Ca}^{2+}$ ) through the interaction with the TP receptor [117]. In murine platelets, interaction of $\mathrm{PGF}_{2 \alpha}$ with the FP receptor could not be confirmed. The partly contradictory results concerning the actions of $\mathrm{PGF}_{2 \alpha}$ in human platelets underline the necessity of further studies on this prostanoid.

Synthetic derivatives of $\mathrm{PGF}_{2 \alpha}$ (Latanoprostene) are used, e.g., in ophthalmology to reduce intraocular pressure [118]. A clinical application as a platelet inhibitor is not in use.

\subsection{Inhibitory Effects of Prostanoids on Platelet Aggregation}

Prostaglandin- $\mathrm{I}_{2}\left(\mathrm{PGI}_{2}\right.$, Prostacyclin)

Prostaglandin- $\mathrm{I}_{2}$ was firstly described by Moncada et al. in 1976 and is majorly synthesized by endothelial cells and smooth muscle cells $[27,119]$. It is metabolized rapidly, and has a very short half-life time of about $42 \mathrm{~s}$ in humans [120], after which it is inactivated (non-enzymatically) and forms 6-ketoprostaglandin- $\mathrm{F}_{1 \alpha}$ [121]. Counteracting the prothrombotic properties of the platelet-derived $\mathrm{TXA}_{2}$, the endothelial $\mathrm{PGI}_{2}$ efficiently inhibits platelet activation, particularly in healthy blood vessels and under elevated shear flow $[27,122-124]$. Its inhibitory potential is higher than that of the other inhibitory prostanoids such as $\mathrm{PGD}_{2}$ and $\mathrm{PGE}_{1}$ [125]. $\mathrm{PGI}_{2}$ binding to the associated IP receptor (coupled to $\mathrm{G}_{\mathrm{s}}$ ) leads to an activation of the AC and thus to an increase of intracellular cAMP. Its elevation downregulates store-mediated calcium entry, calcium mobilization and secretion, as well as platelet adhesion to subendothelial collagen via integrin $\alpha 2 \beta 1$ [31,126-128]. The cAMP increase further results in an activation of protein kinase-A (PKA) and in principle, in an inhibition of platelet activation. Analogous to cAMP, PKA activity has been associated with a reduced $\mathrm{Ca}^{2+}$ release from intra-platelet stores $[129,130]$. However, several other substrates of PKA and respective pathways have been described. Its actions include the regulation of platelet shape change and cytoskeletal proteins, e.g., through phosphorylation of the actin binding protein (ABP) and vasodilator-stimulated phosphoprotein (VASP), or through inhibition of myosin light-chain phosphorylation [131]. Activated PKA also phosphorylates receptors such as GPIb $\beta$ - a subunit of the VWF-binding GPIb-IX complex [132]—and the IP3 receptors on the DTS $[130,133]$. Furthermore, PGI $_{2}$ has a vasodilatory effect, which increases blood flow, particularly in the microvasculature. In addition, $\mathrm{PGI}_{2}$ can also exert long-term effects such as promoting angiogenesis [134], primarily through the receptors IP and EP4 [135].

A study by Smith and Silver revealed that bleeding time in mice lacking this receptor was not different from that in wild-type mice. However, the susceptibility of the receptor-deficient mice to establish thrombosis was increased. These results underline the role of $\mathrm{PGI}_{2}$ in the regulation of thrombus formation [136].

Clinically, these properties are used in the form of $\mathrm{PGI}_{2}$ mimetics (e.g., Epoprostenol, Iloprost, Beraprost, Trepostrinil, Selexipag, etc.) [137]. The most commonly used prostacyclin analogue in pulmonary arterial hypertension (PAH) is Epoprostenol [138]. Other formulations can be used as either IV or inhaled depending on the indication for treatment [139]. Analogues are more stable in vivo compared to the parent molecule and are applied, e.g., to treat patients suffering from PAH [140], critical limb ischemia, Bürger's disease, Raynaud phenomenon and scleroderma diseases [141,142]. A comprehensive review of the complex and not yet fully elucidated mechanisms was provided recently by Lau and Lui [143]. A recently emerging new strategy in vascular diseases (except for PAH) is the local administration of $\mathrm{PGI}_{2}$ analogues to avoid the adverse effects of the systemic application [144].

\subsection{Prostaglandin- $D_{2}\left(P G D_{2}\right)$}

Prostaglandin- $\mathrm{D}_{2}$ is well established as a macrophage (mast cell) product but, in lesser amounts, is also synthesized by platelets. It is a prostaglandin that binds and activates two distinct receptors: $\mathrm{DP}_{1}$ (via $\mathrm{G}_{\alpha(\mathrm{s})} \rightarrow \mathrm{AC}$ ) as well as $\mathrm{DP}_{2}[145,146]$. It is rapidly metabolized enzymatically to 11-epi-prostaglandin- $\mathrm{F}_{2 \alpha}$ or 13,14 dihydro-15-keto-prostaglandin- $\mathrm{D}_{2}$ or non-enzymatically in aqueous solution to prostaglandin- $\mathrm{J}_{2}\left(\mathrm{PGJ}_{2}\right)$ [147]. The apparent half-life time in blood plasma is approximately $30 \mathrm{~min}$, after which it loses its potential to inhibit platelet aggregation. 
$\mathrm{PGD}_{2}$ is known to inhibit platelet aggregation [136], which follows the interaction with the $\mathrm{DP}_{1}$ receptor and AC activation [148]. The inhibitory effect is observed in human platelets-but not in murine platelets-due to the presence or absence of $\mathrm{DP}_{1}$ receptor coupling to $\mathrm{G}_{\mathrm{s}}$.

Shuligoi et al. showed that incubation of plasma with $\mathrm{PGD}_{2}$ causes a time-dependent increase in the half maximal inhibitory concentration $\left(\mathrm{IC}_{50}\right.$ ) for collagen-induced platelet aggregation (factor of $1.9 \%$ after $60 \mathrm{~min}$ and of $6.5 \%$ after $120 \mathrm{~min}$ ) [149]. In this study, the $\mathrm{PGD}_{2}$ metabolite $\mathrm{PGJ}_{2}$ also inhibited collagen-induced platelet aggregation, although, 10- to 30-fold higher concentrations were required. Incubation of $\mathrm{PGJ}_{2}$ in plasma resulted in a very rapid decrease of its inhibitory potency. While the metabolites $\Delta 12-\mathrm{PGJ}_{2}, 15 \mathrm{~d}-\mathrm{PGJ}_{2}$ and $15 \mathrm{~d}$-prostaglandin- $\mathrm{D}_{2}$ had no effect at concentrations up to $1 \mathrm{mM}$, $\Delta 12-\mathrm{PGJ}_{2}$ retained an inhibitory effect on collagen-induced platelet aggregation, which was comparable to $\mathrm{PGJ}_{2}$. The inhibitory potency of $\Delta 12-\mathrm{PGJ}_{2}$ was rapidly decreased by incubation in plasma.

In human platelets, the inhibitory potency of $\mathrm{PGD}_{2}$ was two-times higher than that of prostaglandin- $\mathrm{E}_{1}$, but much less than that of prostacyclin $[125,136]$. The therapeutic potential in cardiovascular diseases has not yet been studied in humans. During the 2000s and until today, several DP2 antagonists were studied in clinical trials for the treatment of asthma $[150,151]$. Antagonists of $\mathrm{PGD}_{2}$ receptor 2 have advanced into phase III clinical trials [152].

\subsection{Prostaglandin- $E_{1}\left(P G E_{1}\right)$}

Prostaglandin- $\mathrm{E}_{1}$ is a product of the arachidonic acid metabolism in many cells and is-to some extent-generated by activated platelets [153-155]. It is largely metabolized during the first lung passage [156,157]. Of the resulting metabolites, the 13,14-dihydro derivate has an antiplatelet effect, like $\mathrm{PGE}_{1}$. The 15-keto-13,14-dihydro derivative has a considerably weaker effect [158]. Prostaglandin- $E_{1}$ stimulates cAMP synthesis and inhibits platelet aggregation [159-161]. In human platelets, it can bind to IP-the $\mathrm{PGI}_{2}$ receptor-as well as to PGE receptors [162]. In mice, the rank order of affinity is EP3 $>$ EP4 $>$ EP2 $>$ EP1 $>$ IP [163]. However, the inhibitory effect of the molecule on human platelet aggregation can be blocked by an IP receptor antagonist but not by an EP4 receptor antagonist [164]. These data suggest that $\mathrm{PGE}_{1}$ inhibits platelet aggregation solely via the IP receptor route.

A synthetic analogue of $\mathrm{PGE}_{1}$, Alprostadil, is in clinical use as a vasodilator to prevent contrast-induced nephropathy or for patients with erectile dysfunction $[165,166]$. $\mathrm{PGE}_{1}$ has also been used for years to treat patients in advanced stages (stage III and IV) of peripheral arterial occlusive disease (see Cochrane Database Review) [167].

\subsection{Prostaglandin- $E_{2}\left(P G E_{2}\right.$, Higher Concentrations)}

In contrast to the response to low $\mathrm{PGE}_{2}$ concentrations, higher doses inhibit platelet activation. This inhibitory effect of $\mathrm{PGE}_{2}$ was significantly blunted but was not entirely abolished in murine platelets lacking IP receptors [168]. However, the affinity of the prostanoid for the human IP receptors appeared to be relatively low [72]. Studies by Smith, Iyú and Philipose indicated an inhibition of platelet aggregation (in mice and humans) by the EP2 and EP4 receptors $[164,169,170]$. Their data suggest that the reduced aggregation results from the selective activation of these receptors. It is noteworthy that the inhibitory potency of an EP4 receptor agonist was two rank orders higher than that of an EP2 receptor agonist and was as high as that of an IP receptor agonist in human platelets [168,171]. Studies in recombinant HEK 293 cells have shown that - at concentrations above $500 \mathrm{nmol} / \mathrm{L}-\mathrm{PGE}_{2}$ can activate the DP1 receptor as well, leading to the above-mentioned cAMP-dependent inhibition of platelet function [172]. $\mathrm{PGE}_{2}$ is used in gynecology for labor induction (Dinoproston) but not as a platelet function inhibitor or in cardiovascular medicine [173,174].

\subsection{Prostaglandin- $E_{3}\left(P G E_{3}\right)$}

This prostaglandin derives from omega-3 fatty acids and is synthesized by COX from eicosapentaenoic acid (EPA) $[175,176]$. It was reported to have anti-proliferative effects in different cancer 
cells [176], is involved in tumor angiogenesis [177] and can influence endothelial cell integrity [178,179]. A study by Iyu revealed a reduced platelet aggregation (PAF-induced) and expression of plasma membrane P-Selectin (U46619-induced) when platelets of human origin were treated with $\mathrm{PGE}_{3}$. These effects were concentration-dependent and enhanced when an EP3 receptor antagonist was applied additionally. In contrast, effects were inhibited when the EP4 receptor was antagonized, but were not influenced by an IP receptor antagonist. The overall influence of $\mathrm{PGE}_{3}$ on platelet function is consequently balanced by EP3 and EP4 receptor activation, which is in accordance with the $\mathrm{PGE}_{2}$ (EP3) but not the $\mathrm{PGE}_{1}$ (IP) receptor routes. These data indicate a potential mechanism of how omega-3 fatty acids-the precursors of $\mathrm{PGE}_{3}$ - might influence platelet function [180-182]. At present, too little data is available on this aspect.

\section{Conclusions}

The understanding of the action of prostanoids and their receptors has led to the development of anti-platelet agents $[183,184]$. These are applied to prevent thrombotic events such as myocardial infarction or cerebral thrombosis [185], the major causes of death in developed countries [186]. The rank of order of potency of platelet activation inhibitors is: $\mathrm{PGI}_{2}>6$-keto-PGE $1>\mathrm{PGD}_{2}>6$-keto- $\mathrm{PGF}_{2 \alpha}>$ $\mathrm{PGE}_{2}>\mathrm{PGF}_{2 \alpha}$ [187]. The order reflects the importance of the prostacyclin receptor in mediating effects of prostaglandin on the platelet adenylyl cyclase. The targets of aspirin, prasugrel or cilostazol are cyclooxygenase, $\mathrm{ADP}$ receptor $\mathrm{P}_{2} \mathrm{Y}_{12}$ and phosphodiesterase. Although a $\mathrm{PGI}_{2}$ receptor agonist $\left(\mathrm{PGI}_{2}\right.$ or $\mathrm{PGE}_{1}$ analogue) and a thromboxane synthase inhibitor have been used for anti-platelet therapy, there are still no anti-platelet agents targeting PGE receptors in clinical use. Previous studies revealed a role of the EP3 receptor in thromboembolism $[63,70,188]$ and higher inhibitory potency of a EP4 agonist in platelet aggregation [168]. Altogether, the discussed data suggest a potential of respective antagonists and agonists as novel anti-platelet agents $[169,189]$.

Author Contributions: F.J. and S.B. designed the review. All authors performed the literature search and wrote the paper. F.J designed the table and S.B. the figures. All authors revised the manuscript critically. All authors finally approved the article and have read and agreed to the published version of the manuscript.

Funding: This research was funded by the European Regional Development Fund (EFRE), grant number 85036717.

Conflicts of Interest: The authors declare no conflict of interest.

\section{References}

1. Agbani, E.O.; Williams, C.M.; Hers, I.; Poole, A.W. Membrane ballooning in aggregated platelets is synchronised and mediates a surge in microvesiculation. Sci. Rep. 2017, 7, 2770. [CrossRef] [PubMed]

2. Rubenstein, D.A.; Yin, W. Platelet-activation mechanisms and vascular remodeling. Compr. Physiol. 2018, 8, 1117-1156. [CrossRef] [PubMed]

3. Faes, C.; Sparkenbaugh, E.M.; Pawlinski, R. Hypercoagulable state in sickle cell disease. Clin. Hemorheol. Microcirc. 2018, 68, 301-318. [CrossRef] [PubMed]

4. Reinthaler, M.; Braune, S.; Lendlein, A.; Landmesser, U.; Jung, F. Platelets and coronary artery disease: Interactions with the blood vessel wall and cardiovascular devices. Biointerphases 2016, 11, 029702. [CrossRef] [PubMed]

5. Ezer, E.; Schrick, D.; Tőkés-Füzesi, M.; Szapary, L.; Bogar, L.; Molnar, T. A novel approach of platelet function test for prediction of attenuated response to clopidogrel. Clin. Hemorheol. Microcirc. 2019, 73, 359-369. [CrossRef] [PubMed]

6. Ullrich, H.; Gori, T. The pleiotropic effects of antiplatelet therapies. Clin. Hemorheol. Microcirc. 2019, 73, 29-34. [CrossRef]

7. Gregg, D. Platelets and cardiovascular disease. Circulation 2003, 108, 88e-90e. [CrossRef]

8. Lippi, G.; Franchini, M.; Targher, G. Arterial thrombus formation in cardiovascular disease. Nat. Rev. Cardiol. 2011, 8, 502-512. [CrossRef]

9. Trip, M.D.; Cats, V.M.; van Capelle, F.J.; Vreeken, J. Platelet hyperreactivity and prognosis in survivors of myocardial infarction. N. Engl. J. Med. 1990, 322, 1549-1554. [CrossRef] 
10. Willoughby, S. Platelets and cardiovascular disease. Eur. J. Cardiovasc. Nurs. 2002, 1, 273-288. [CrossRef]

11. Jung, F.; Wischke, C.; Lendlein, A. Degradable, multifunctional cardiovascular implants: Challenges and hurdles. MRS Bull. 2010, 35, 607-613. [CrossRef]

12. Otsuka, F.; Cheng, Q.; Yahagi, K.; Acampado, E.; Sheehy, A.; Yazdani, S.K.; Sakakura, K.; Euller, K.; Perkins, L.E.L.; Kolodgie, F.D.; et al. Acute thrombogenicity of a durable polymer everolimus-eluting stent relative to contemporary drug-eluting stents with biodegradable polymer coatings assessed ex vivo in a swine shunt model. JACC Cardiovasc. Interv. 2015, 8, 1248-1260. [CrossRef] [PubMed]

13. Anadol, R.; Dimitriadis, Z.; Polimeni, A.; Wendling, F.; Gönner, S.; Ullrich, H.; Lorenz, L.; Weissner, M.; Munzel, T.; Gori, T. Bioresorbable everolimus-eluting vascular scaffold for patients presenting with non STelevation-acute coronary syndrome: A three-years follow-up1. Clin. Hemorheol. Microcirc. 2018, 69, 3-8. [CrossRef] [PubMed]

14. Holinstat, M. Normal platelet function. Cancer Metastasis Rev. 2017, 36, 195-198. [CrossRef] [PubMed]

15. Lapetina, E.G.; Cuatrecasas, P. Rapid inactivation of cyclooxygenase activity after stimulation of intact platelets. Proc. Natl. Acad. Sci. USA 1979, 76, 121-125. [CrossRef]

16. Gerrard, J.M.; White, J.G.; Rao, G.H.; Townsend, D. Localization of platelet prostaglandin production in the platelet dense tubular system. Am. J. Pathol. 1976, 83, 283-298.

17. Gerrard, J.M.; White, J.G.; Peterson, D.A. The Platelet dense tubular system: Its Relationship to prostaglandin synthesis and calcium flux. Thromb. Haemost. 1978, 40, 224-231. [CrossRef]

18. Rendu, F.; Brohard-Bohn, B. The platelet release reaction: Granules' constituents, secretion and functions. Platelets 2001, 12, 261-273. [CrossRef]

19. Kennedy, I.; Coleman, R.A.; Humphrey, P.P.; Levy, G.P.; Lumley, P. Studies on the characterisation of prostanoid receptors: A proposed classification. Prostaglandins 1982, 24, 667-689. [CrossRef]

20. Coleman, R.A.; Andrianova, I.; Humphrey, P.P.A.; Adrian, K.; Bath, P.M. Prostanoids and their receptors. In Comprehensive Medicinal Chemistry: The Rational Design, Mechanistic Study \& Therapeutic Application of Chemical Compounds; Membranes and Receptors; Emmett, J.C., Ed.; Pergamon: Oxford, UK, 1990; Volume 3, pp. 643-714.

21. Lebender, L.F.; Prünte, L.; Rumzhum, N.N.; Ammit, A.J. Selectively targeting prostanoid E (EP) receptor-mediated cell signalling pathways: Implications for lung health and disease. Pulm. Pharmacol. Ther. 2018, 49, 75-87. [CrossRef]

22. Sugimoto, Y.; Negishi, M.; Hayashi, Y.; Namba, T.; Honda, A.; Watabe, A.; Hirata, M.; Narumiya, S.; Ichikawa, A. Two isoforms of the EP3 receptor with different carboxyl-terminal domains. Identical ligand binding properties and different coupling properties with Gi proteins. J. Biol. Chem. 1993, 268, 2712-2718. [PubMed]

23. Irie, A.; Sugimoto, Y.; Namba, T.; Harazono, A.; Honda, A.; Watabe, A.; Negishi, M.; Narumiya, S.; Ichikawa, A. Third isoform of the prostaglandin-E-receptor EP3 subtype with different C-terminal tail coupling to both stimulation and inhibition of adenylate cyclase. Eur. J. Biochem. 1993, 217, 313-318. [CrossRef] [PubMed]

24. Hirai, H.; Tanaka, K.; Yoshie, O.; Ogawa, K.; Kenmotsu, K.; Takamori, Y.; Ichimasa, M.; Sugamura, K.; Nakamura, M.; Takano, S.; et al. Prostaglandin D2 selectively induces chemotaxis in T helper type 2 cells, eosinophils, and basophils via seven-transmembrane receptor CRTH2. J. Exp. Med. 2001, 193, 255-261. [CrossRef] [PubMed]

25. Ozen, G.; Norel, X. Prostanoids in the pathophysiology of human coronary artery. Prostaglandins Other Lipid Mediat. 2017, 133, 20-28. [CrossRef] [PubMed]

26. Hamberg, M.; Svensson, J.; Samuelsson, B. Thromboxanes: A new group of biologically active compounds derived from prostaglandin endoperoxides. Proc. Natl. Acad. Sci. USA 1975, 72, 2994-2998. [CrossRef] [PubMed]

27. Moncada, S.; Gryglewski, R.; Bunting, S.; Vane, J.R. An enzyme isolated from arteries transforms prostaglandin endoperoxides to an unstable substance that inhibits platelet aggregation. Nature 1976, 263, 663-665. [CrossRef] [PubMed]

28. Packham, M.A.; Rand, M.L.; Kinlough-Rathbone, R.L. Similarities and differences between rabbit and human platelet characteristics and functions. Comp. Biochem. Physiol. Comp. Physiol. 1992, 103, 35-54. [CrossRef]

29. Paul, B.Z.; Ashby, B.; Sheth, S.B. Distribution of prostaglandin IP and EP receptor subtypes and isoforms in platelets and human umbilical artery smooth muscle cells. Br. J. Haematol. 1998, 102, 1204-1211. [CrossRef] 
30. Procter, N.E.K.; Hurst, N.L.; Nooney, V.B.; Imam, H.; De Caterina, R.; Chirkov, Y.Y.; Horowitz, J.D. New developments in platelet cyclic nucleotide signalling: Therapeutic implications. Cardiovasc. Drugs Ther. 2016, 30, 505-513. [CrossRef]

31. Schwarz, U.R.; Walter, U.; Eigenthaler, M. Taming platelets with cyclic nucleotides. Biochem. Pharmacol. 2001, 62, 1153-1161. [CrossRef]

32. Yokoyama, U.; Iwatsubo, K.; Umemura, M.; Fujita, T.; Ishikawa, Y. The prostanoid EP4 receptor and its signaling pathway. Pharmacol. Rev. 2013, 65, 1010-1052. [CrossRef] [PubMed]

33. Nakamura, Y.; Fukami, K. Regulation and physiological functions of mammalian phospholipase C. J. Biochem. 2017, 161, 315-321. [CrossRef] [PubMed]

34. Mitchell, J.A.; Kirkby, N.S. Eicosanoids, prostacyclin and cyclooxygenase in the cardiovascular system. Br. J. Pharmacol. 2019, 176, 1038-1050. [CrossRef] [PubMed]

35. Crescente, M.; Menke, L.; Chan, M.V.; Armstrong, P.C.; Warner, T.D. Eicosanoids in platelets and the effect of their modulation by aspirin in the cardiovascular system (and beyond). Br. J. Pharmacol. 2019, 176, 988-999. [CrossRef]

36. Krüger-Genge, A.; Schulz, C.; Kratz, K.; Lendlein, A.; Jung, F. Comparison of two substrate materials used as negative control in endothelialization studies: Glass versus polymeric tissue culture plate. Clin. Hemorheol. Microcirc. 2018, 69, 437-445. [CrossRef]

37. Hauser, S.; Jung, F.; Pietzsch, J. Human endothelial cell models in biomaterial research. Trends Biotechnol. 2017, 35, 265-277. [CrossRef]

38. FitzGerald, G.A. Mechanisms of platelet activation: Thromboxane A2 as an amplifying signal for other agonists. Am. J. Cardiol. 1991, 68, 11B-15B. [CrossRef]

39. Lagarde, M.; Guichardant, M.; Bernoud-Hubac, N.; Calzada, C.; Véricel, E. Oxygenation of polyunsaturated fatty acids and oxidative stress within blood platelets. Biochim. Biophys. Acta Mol. Cell Biol. Lipids 2018, 1863, 651-656. [CrossRef]

40. Patrono, C.; Ciabattoni, G.; Pugliese, F.; Pierucci, A.; Blair, I.A.; FitzGerald, G.A. Estimated rate of thromboxane secretion into the circulation of normal humans. J. Clin. Investig. 1986, 77, 590-594. [CrossRef]

41. Viinikka, L.; Ylikorkala, O. Measurement of thromboxane B2 in human plasma or serum by radioimmunoassay. Prostaglandins 1980, 20, 759-766. [CrossRef]

42. Patrono, C.; Rocca, B. Measurement of thromboxane biosynthesis in health and disease. Front. Pharmacol. 2019, 10, 1244. [CrossRef]

43. Simmons, D.L.; Botting, R.M.; Hla, T. Cyclooxygenase isozymes: The biology of prostaglandin synthesis and inhibition. Pharmacol. Rev. 2004, 56, 387-437. [CrossRef] [PubMed]

44. Friedman, E.A.; Ogletree, M.L.; Haddad, E.V.; Boutaud, O. Understanding the role of prostaglandin E2 in regulating human platelet activity in health and disease. Thromb. Res. 2015, 136, 493-503. [CrossRef] [PubMed]

45. Offermanns, S. Activation of platelet function through G protein-coupled receptors. Circ. Res. 2006, 99, 1293-1304. [CrossRef] [PubMed]

46. Zatta, A.; Prosdocimi, M. Platelet activation induced by a stable analogue of endoperoxides (U46619). Thromb. Haemost. 1989, 61, 328-329. [CrossRef] [PubMed]

47. Reilly, M.; Fitzgerald, G.A. Cellular activation by thromboxane A2 and other eicosanoids. Eur. Heart J. 1993, 14 (Suppl. K), 88-93. [PubMed]

48. Fuse, I.; Higuchi, W.; Aizawa, Y. Pathogenesis of a bleeding disorder characterized by platelet unresponsiveness to thromboxane A2. Semin. Thromb. Hemost. 2000, 26, 43-45. [CrossRef]

49. Hirata, T.; Kakizuka, A.; Ushikubi, F.; Fuse, I.; Okuma, M.; Narumiya, S. Arg60 to Leu mutation of the human thromboxane A2 receptor in a dominantly inherited bleeding disorder. J. Clin. Investig. 1994, 94, 1662-1667. [CrossRef]

50. Oates, J.A.; FitzGerald, G.A.; Branch, R.A.; Jackson, E.K.; Knapp, H.R.; Roberts, L.J. Clinical implications of prostaglandin and thromboxane A2 formation (1). N. Engl. J. Med. 1988, 319, 689-698. [CrossRef]

51. Malmsten, C.; Hamberg, M.; Svensson, J.; Samuelsson, B. Physiological role of an endoperoxide in human platelets: Hemostatic defect due to platelet cyclo-oxygenase deficiency. Proc. Natl. Acad. Sci. USA 1975, 72, 1446-1450. [CrossRef] 
52. Defreyn, G.; Deckmyn, H.; Vermylen, J. A thromboxane synthetase inhibitor reorients endoperoxide metabolism in whole blood towards prostacyclin and prostaglandin E2. Thromb. Res. 1982, 26, 389-400. [CrossRef]

53. Defreyn, G.; Machin, S.J.; Carreras, L.O.; Dauden, M.V.; Chamone, D.A.; Vermylen, J. Familial bleeding tendency with partial platelet thromboxane synthetase deficiency: Reorientation of cyclic endoperoxide metabolism. Br. J. Haematol. 1981, 49, 29-41. [CrossRef] [PubMed]

54. Vermylen, J.; Defreyn, G.; Carreras, L.O.; Machin, S.J.; Van Schaeren, J.; Verstraete, M. Thromboxane synthetase inhibition as antithrombotic strategy. Lancet 1981, 1, 1073-1075. [CrossRef]

55. Gresele, P.; Arnout, J.; Deckmyn, H.; Huybrechts, E.; Pieters, G.; Vermylen, J. Role of proaggregatory and antiaggregatory prostaglandins in hemostasis. Studies with combined thromboxane synthase inhibition and thromboxane receptor antagonism. J. Clin. Investig. 1987, 80, 1435-1445. [CrossRef] [PubMed]

56. Rosenfeld, L.; Grover, G.J.; Stier, C.T. Ifetroban sodium: An effective TxA2/PGH2 receptor antagonist. Cardiovasc. Drug Rev. 2001, 19, 97-115. [CrossRef]

57. Bousser, M.-G.; Amarenco, P.; Chamorro, A.; Fisher, M.; Ford, I.; Fox, K.M.; Hennerici, M.G.; Mattle, H.P.; Rothwell, P.M.; de Cordoüe, A.; et al. Terutroban versus aspirin in patients with cerebral ischaemic events (PERFORM): A randomised, double-blind, parallel-group trial. Lancet 2011, 377, 2013-2022. [CrossRef]

58. Schrey, M.P.; Patel, K.V. Prostaglandin E2 production and metabolism in human breast cancer cells and breast fibroblasts. Regulation by inflammatory mediators. Br. J. Cancer 1995, 72, 1412-1419. [CrossRef] [PubMed]

59. Tammali, R.; Ramana, K.V.; Srivastava, S.K. Aldose reductase regulates TNF-alpha-induced PGE2 production in human colon cancer cells. Cancer Lett. 2007, 252, 299-306. [CrossRef]

60. Delamere, F.; Holland, E.; Patel, S.; Bennett, J.; Pavord, I.; Knox, A. Production of PGE2 by bovine cultured airway smooth muscle cells and its inhibition by cyclo-oxygenase inhibitors. Br. J. Pharmacol. 1994, 111, 983-988. [CrossRef]

61. Charo, I.F.; Shak, S.; Karasek, M.A.; Davison, P.M.; Goldstein, I.M. Prostaglandin I2 is not a major metabolite of arachidonic acid in cultured endothelial cells from human foreskin microvessels. J. Clin. Investig. 1984, 74, 914-919. [CrossRef]

62. Kuwano, T.; Nakao, S.; Yamamoto, H.; Tsuneyoshi, M.; Yamamoto, T.; Kuwano, M.; Ono, M. Cyclooxygenase 2 is a key enzyme for inflammatory cytokine-induced angiogenesis. FASEB J. 2004, 18, 300-310. [CrossRef] [PubMed]

63. Gross, S.; Tilly, P.; Hentsch, D.; Vonesch, J.-L.; Fabre, J.-E. Vascular wall-produced prostaglandin E2 exacerbates arterial thrombosis and atherothrombosis through platelet EP3 receptors. J. Exp. Med. 2007, 204, 311-320. [CrossRef] [PubMed]

64. Cipollone, F.; Prontera, C.; Pini, B.; Marini, M.; Fazia, M.; De Cesare, D.; Iezzi, A.; Ucchino, S.; Boccoli, G.; Saba, V.; et al. Overexpression of functionally coupled cyclooxygenase-2 and prostaglandin E synthase in symptomatic atherosclerotic plaques as a basis of prostaglandin E(2)-dependent plaque instability. Circulation 2001, 104, 921-927. [CrossRef]

65. Gomez, I.; Foudi, N.; Longrois, D.; Norel, X. The role of prostaglandin E2 in human vascular inflammation. Prostaglandins Leukot. Essent. Fat. Acids 2013, 89, 55-63. [CrossRef]

66. Shio, H.; Ramwell, P. Effect of prostaglandin E 2 and aspirin on the secondary aggregation of human platelets. Nat. New Biol. 1972, 236, 45-46. [CrossRef] [PubMed]

67. McDonald, J.W.; Stuart, R.K. Interaction of prostaglandins E1 and E2 in regulation of cyclic-AMP and aggregation in human platelets: Evidence for a common prostaglandin receptor. J. Lab. Clin. Med. 1974, 84, 111-121.

68. Gray, S.J.; Heptinstall, S. The effects of PGE2 and CL 115,347, an antihypertensive PGE2 analogue, on human blood platelet behaviour and vascular contractility. Eur. J. Pharmacol. 1985, 114, 129-137. [CrossRef]

69. Gray, S.J.; Heptinstall, S. Interactions between prostaglandin E2 and inhibitors of platelet aggregation which act through cyclic AMP. Eur. J. Pharmacol. 1991, 194, 63-70. [CrossRef]

70. Ma, H.; Hara, A.; Xiao, C.Y.; Okada, Y.; Takahata, O.; Nakaya, K.; Sugimoto, Y.; Ichikawa, A.; Narumiya, S.; Ushikubi, F. Increased bleeding tendency and decreased susceptibility to thromboembolism in mice lacking the prostaglandin E receptor subtype EP(3). Circulation 2001, 104, 1176-1180. [CrossRef]

71. Smith, J.P.; Haddad, E.V.; Downey, J.D.; Breyer, R.M.; Boutaud, O. PGE2 decreases reactivity of human platelets by activating EP2 and EP4. Thromb. Res. 2010, 126, e23-e29. [CrossRef] 
72. Iyú, D.; Glenn, J.R.; White, A.E.; Johnson, A.J.; Fox, S.C.; Heptinstall, S. The role of prostanoid receptors in mediating the effects of PGE(2) on human platelet function. Platelets 2010, 21, 329-342. [CrossRef] [PubMed]

73. Petrucci, G.; De Cristofaro, R.; Rutella, S.; Ranelletti, F.O.; Pocaterra, D.; Lancellotti, S.; Habib, A.; Patrono, C.; Rocca, B. Prostaglandin E2 differentially modulates human platelet function through the prostanoid EP2 and EP3 receptors. J. Pharmacol. Exp. Ther. 2011, 336, 391-402. [CrossRef] [PubMed]

74. Andersen, N.H.; Eggerman, T.L.; Harker, L.A.; Wilson, C.H.; De, B. On the multiplicity of platelet prostaglandin receptors. I. Evaluation of competitive antagonism by aggregometry. Prostaglandins 1980, 19, 711-735. [CrossRef]

75. Tynan, S.S.; Andersen, N.H.; Wills, M.T.; Harker, L.A.; Hanson, S.R. On the multiplicity of platelet prostaglandin receptors. II. The use of N-0164 for distinguishing the loci of action for PGI2, PGD2, PGE2 and hydantoin analogs. Prostaglandins 1984, 27, 683-696. [CrossRef]

76. Hubertus, K.; Mischnik, M.; Timmer, J.; Herterich, S.; Mark, R.; Moulard, M.; Walter, U.; Geiger, J. Reciprocal regulation of human platelet function by endogenous prostanoids and through multiple prostanoid receptors. Eur. J. Pharmacol. 2014, 740, 15-27. [CrossRef]

77. Schaid, M.D.; Wisinski, J.A.; Kimple, M.E. The EP3 receptor/Gz signaling axis as a therapeutic target for diabetes and cardiovascular disease. AAPS J. 2017, 19, 1276-1283. [CrossRef] [PubMed]

78. Yang, J.; Wu, J.; Kowalska, M.A.; Dalvi, A.; Prevost, N.; O’Brien, P.J.; Manning, D.; Poncz, M.; Lucki, I.; Blendy, J.A.; et al. Loss of signaling through the $\mathrm{G}$ protein, $\mathrm{Gz}$, results in abnormal platelet activation and altered responses to psychoactive drugs. Proc. Natl. Acad. Sci. USA 2000, 97, 9984-9989. [CrossRef]

79. Yang, J.; Wu, J.; Jiang, H.; Mortensen, R.; Austin, S.; Manning, D.R.; Woulfe, D.; Brass, L.F. Signaling through Gi family members in platelets. Redundancy and specificity in the regulation of adenylyl cyclase and other effectors. J. Biol. Chem. 2002, 277, 46035-46042. [CrossRef]

80. Namba, T.; Sugimoto, Y.; Negishi, M.; Irie, A.; Ushikubi, F.; Kakizuka, A.; Ito, S.; Ichikawa, A.; Narumiya, S. Alternative splicing of C-terminal tail of prostaglandin E receptor subtype EP3 determines G-protein specificity. Nature 1993, 365, 166-170. [CrossRef]

81. Jin, J.; Mao, G.F.; Ashby, B. Constitutive activity of human prostaglandin E receptor EP3 isoforms. Br. J. Pharmacol. 1997, 121, 317-323. [CrossRef]

82. Coleman, R.A.; Grix, S.P.; Head, S.A.; Louttit, J.B.; Mallett, A.; Sheldrick, R.L. A novel inhibitory prostanoid receptor in piglet saphenous vein. Prostaglandins 1994, 47, 151-168. [CrossRef]

83. Nagy, Z.; Smolenski, A. Cyclic nucleotide-dependent inhibitory signaling interweaves with activating pathways to determine platelet responses. Res. Pract. Thromb. Haemost. 2018, 2, 558-571. [CrossRef] [PubMed]

84. Bos, J.L. Epac: A new cAMP target and new avenues in cAMP research. Nat. Rev. Mol. Cell Biol. 2003, 4, 733-738. [CrossRef] [PubMed]

85. Stefanini, L.; Bergmeier, W. RAP1-GTPase signaling and platelet function. J. Mol. Med. (Berl.) 2016, 94, 13-19. [CrossRef]

86. Vilahur, G.; Gutiérrez, M.; Arzanauskaite, M.; Mendieta, G.; Ben-Aicha, S.; Badimon, L. Intracellular platelet signalling as a target for drug development. Vascul. Pharmacol. 2018, 111, 22-25. [CrossRef]

87. Wang, Z.; Dillon, T.J.; Pokala, V.; Mishra, S.; Labudda, K.; Hunter, B.; Stork, P.J.S. Rap1-mediated activation of extracellular signal-regulated kinases by cyclic AMP is dependent on the mode of Rap1 activation. Mol. Cell Biol. 2006, 26, 2130-2145. [CrossRef]

88. Takahashi, M.; Li, Y.; Dillon, T.J.; Stork, P.J.S. Phosphorylation of Rap1 by cAMP-dependent Protein Kinase (PKA) creates a binding site for KSR to sustain ERK activation by cAMP. J. Biol. Chem. 2017, 292, 1449-1461. [CrossRef]

89. De Rooij, J.; Zwartkruis, F.J.; Verheijen, M.H.; Cool, R.H.; Nijman, S.M.; Wittinghofer, A.; Bos, J.L. Epac is a Rap1 guanine-nucleotide-exchange factor directly activated by cyclic AMP. Nature 1998, 396, 474-477. [CrossRef]

90. Lacabaratz-Porret, C.; Corvazier, E.; Kovàcs, T.; Bobe, R.; Bredoux, R.; Launay, S.; Papp, B.; Enouf, J. Platelet sarco/endoplasmic reticulum Ca2+ATPase isoform $3 \mathrm{~b}$ and Rap 1b: Interrelation and regulation in physiopathology. Biochem. J. 1998, 332(Pt 1), 173-181. [CrossRef]

91. Kosuru, R.; Chrzanowska, M. Integration of Rap1 and calcium signaling. IJMS 2020, 21, 1616. [CrossRef]

92. Schmidt, M.; Sand, C.; Jakobs, K.H.; Michel, M.C.; Weernink, P.A.O. Epac and the cardiovascular system. Curr. Opin. Pharmacol. 2007, 7, 193-200. [CrossRef] [PubMed] 
93. Desai, S.; Ashby, B. Agonist-induced internalization and mitogen-activated protein kinase activation of the human prostaglandin EP4 receptor. FEBS Lett. 2001, 501, 156-160. [CrossRef]

94. Takayama, K.; Sukhova, G.K.; Chin, M.T.; Libby, P. A novel prostaglandin E receptor 4-associated protein participates in antiinflammatory signaling. Circ. Res. 2006, 98, 499-504. [CrossRef] [PubMed]

95. Fujino, H.; Xu, W.; Regan, J.W. Prostaglandin E2 induced functional expression of early growth response factor-1 by EP4, but not EP2, prostanoid receptors via the phosphatidylinositol 3-kinase and extracellular signal-regulated kinases. J. Biol. Chem. 2003, 278, 12151-12156. [CrossRef] [PubMed]

96. Fujino, H.; West, K.A.; Regan, J.W. Phosphorylation of glycogen synthase kinase-3 and stimulation of T-cell factor signaling following activation of EP2 and EP4 prostanoid receptors by prostaglandin E2. J. Biol. Chem. 2002, 277, 2614-2619. [CrossRef] [PubMed]

97. Gresele, P.; Blockmans, D.; Deckmyn, H.; Vermylen, J. Adenylate cyclase activation determines the effect of thromboxane synthase inhibitors on platelet aggregation in vitro. Comparison of platelets from responders and nonresponders. J. Pharmacol. Exp. Ther. 1988, 246, 301-307.

98. Matthews, J.S.; Jones, R.L. Potentiation of aggregation and inhibition of adenylate cyclase in human platelets by prostaglandin E analogues. Br. J. Pharmacol. 1993, 108, 363-369. [CrossRef]

99. Gresele, P.; Deckmyn, H.; Huybrechts, E.; Vermylen, J. Serum albumin enhances the impairment of platelet aggregation with thromboxane synthase inhibition by increasing the formation of prostaglandin D2. Biochem. Pharmacol. 1984, 33, 2083-2088. [CrossRef]

100. Watanabe, K.; Yoshida, R.; Shimizu, T.; Hayaishi, O. Enzymatic formation of prostaglandin F2 alpha from prostaglandin $\mathrm{H} 2$ and D2. Purification and properties of prostaglandin F synthetase from bovine lung. J. Biol. Chem. 1985, 260, 7035-7041.

101. Basu, S.; Sjöquist, B.; Resul, B.; Stjernschantz, J. Presence of a 15-ketoprostaglandin delta 13-reductase in porcine cornea. Acta Chem. Scand. 1992, 46, 108-110. [CrossRef]

102. Basu, S. Novel cyclooxygenase-catalyzed bioactive prostaglandin F2alpha from physiology to new principles in inflammation. Med. Res. Rev. 2007, 27, 435-468. [CrossRef] [PubMed]

103. Hao, C.-M.; Breyer, M.D. Physiological regulation of prostaglandins in the kidney. Annu. Rev. Physiol. 2008, 70, 357-377. [CrossRef] [PubMed]

104. Sales, K.J.; List, T.; Boddy, S.C.; Williams, A.R.W.; Anderson, R.A.; Naor, Z.; Jabbour, H.N. A novel angiogenic role for prostaglandin F2alpha-FP receptor interaction in human endometrial adenocarcinomas. Cancer Res. 2005, 65, 7707-7716. [CrossRef] [PubMed]

105. Kim, Y.T.; Moon, S.K.; Maruyama, T.; Narumiya, S.; Doré, S. Prostaglandin FP receptor inhibitor reduces ischemic brain damage and neurotoxicity. Neurobiol. Dis. 2012, 48, 58-65. [CrossRef]

106. Glushakov, A.V.; Robbins, S.W.; Bracy, C.L.; Narumiya, S.; Doré, S. Prostaglandin F2 $\alpha$ FP receptor antagonist improves outcomes after experimental traumatic brain injury. J. Neuroinflamm. 2013, 10, 132. [CrossRef]

107. Watanabe, T.; Nakao, A.; Emerling, D.; Hashimoto, Y.; Tsukamoto, K.; Horie, Y.; Kinoshita, M.; Kurokawa, K. Prostaglandin F2 alpha enhances tyrosine phosphorylation and DNA synthesis through phospholipase C-coupled receptor via $\mathrm{Ca}(2+)$-dependent intracellular pathway in NIH-3T3 cells. J. Biol. Chem. 1994, 269, 17619-17625.

108. Sugimoto, Y.; Yamasaki, A.; Segi, E.; Tsuboi, K.; Aze, Y.; Nishimura, T.; Oida, H.; Yoshida, N.; Tanaka, T.; Katsuyama, M.; et al. Failure of parturition in mice lacking the prostaglandin F receptor. Science 1997, 277, 681-683. [CrossRef]

109. Zhang, J.; Gong, Y.; Yu, Y. PG F2 $\alpha$ receptor: A promising therapeutic target for cardiovascular disease. Front. Pharmacol. 2010, 1. [CrossRef]

110. Yu, Y.; Lucitt, M.B.; Stubbe, J.; Cheng, Y.; Friis, U.G.; Hansen, P.B.; Jensen, B.L.; Smyth, E.M.; FitzGerald, G.A. Prostaglandin F2 elevates blood pressure and promotes atherosclerosis. Proc. Natl. Acad. Sci. USA 2009, 106, 7985-7990. [CrossRef]

111. Rabinowitz, B.; Arad, M.; Elazar, E.; Klein, R.; Zahav, Y.H. Epicardial versus endocardial "in mirror" changes in prostaglandin synthesis after short periods of ischemia and reperfusion. Eicosanoids 1992, 5, 163-167.

112. Di Francesco, L.; Totani, L.; Dovizio, M.; Piccoli, A.; Di Francesco, A.; Salvatore, T.; Pandolfi, A.; Evangelista, V.; Dercho, R.A.; Seta, F.; et al. Induction of prostacyclin by steady laminar shear stress suppresses tumor necrosis factor-alpha biosynthesis via heme oxygenase-1 in human endothelial cells. Circ. Res. 2009, 104, 506-513. [CrossRef] [PubMed] 
113. Rice, K.M.; Uddemarri, S.; Desai, D.H.; Morrison, R.G.; Harris, R.; Wright, G.L.; Blough, E.R. PGF2alpha-associated vascular smooth muscle hypertrophy is ROS dependent and involves the activation of mTOR, p70S6k, and PTEN. Prostaglandins Other Lipid Mediat. 2008, 85, 49-57. [CrossRef] [PubMed]

114. Whittle, B.J.; Oren-Wolman, N.; Guth, P.H. Gastric vasoconstrictor actions of leukotriene C4, PGF2 alpha, and thromboxane mimetic U-46619 on rat submucosal microcirculation in vivo. Am. J. Physiol. 1985, 248, G580-G586. [CrossRef] [PubMed]

115. Hung, S.C.; Ghali, N.I.; Venton, D.L.; Le Breton, G.C. Prostaglandin F2 alpha antagonizes thromboxane A2-induced human platelet aggregation. Prostaglandins 1982, 24, 195-206. [CrossRef]

116. Armstrong, R.A.; Jones, R.L.; Wilson, N.H. Mechanism of the inhibition of platelet aggregation produced by prostaglandin F2 alpha. Prostaglandins 1985, 29, 601-610. [CrossRef]

117. Kashiwagi, H.; Yuhki, K.; Imamichi, Y.; Kojima, F.; Kumei, S.; Tasaki, Y.; Narumiya, S.; Ushikubi, F. Prostaglandin F2 $\alpha$ facilitates platelet activation by acting on prostaglandin E2 receptor subtype EP3 and thromboxane A2 receptor TP in mice. Thromb. Haemost. 2019, 119, 1311-1320. [CrossRef]

118. Rulo, A.H.; Greve, E.L.; Hoyng, P.F. Additive effect of latanoprost, a prostaglandin F2 alpha analogue, and timolol in patients with elevated intraocular pressure. Br. J. Ophthalmol. 1994, 78, 899-902. [CrossRef]

119. Chu, L.; Liou, J.-Y.; Wu, K.K. Prostacyclin protects vascular integrity via PPAR/14-3-3 pathway. Prostaglandins Other Lipid Mediat. 2015, 118-119, 19-27. [CrossRef]

120. Cawello, W.; Schweer, H.; Müller, R.; Bonn, R.; Seyberth, H.W. Metabolism and pharmacokinetics of prostaglandin E1 administered by intravenous infusion in human subjects. Eur. J. Clin. Pharmacol. 1994, 46, 275-277. [CrossRef]

121. Lewis, P.J.; Dollery, C.T. Clinical pharmacology and potential of prostacyclin. Br. Med. Bull. 1983, 39, $281-284$. [CrossRef]

122. Borgdorff, P.; Tangelder, G.J.; Paulus, W.J. Cyclooxygenase-2 inhibitors enhance shear stress-induced platelet aggregation. J. Am. Coll. Cardiol. 2006, 48, 817-823. [CrossRef] [PubMed]

123. Weiss, H.J.; Turitto, V.T. Prostacyclin (prostaglandin I2, PGI2) inhibits platelet adhesion and thrombus formation on subendothelium. Blood 1979, 53, 244-250. [CrossRef] [PubMed]

124. Adelman, B.; Stemerman, M.B.; Mennell, D.; Handin, R.I. The interaction of platelets with aortic subendothelium: Inhibition of adhesion and secretion by prostaglandin I2. Blood 1981, 58, 198-205. [CrossRef] [PubMed]

125. Whittle, B.J.; Moncada, S.; Vane, J.R. Comparison of the effects of prostacyclin (PGI2), prostaglandin E1 and D2 on platelet aggregation in different species. Prostaglandins 1978, 16, 373-388. [CrossRef]

126. Polanowska-Grabowska, R.; Gear, A.R. Role of cyclic nucleotides in rapid platelet adhesion to collagen. Blood 1994, 83, 2508-2515. [CrossRef]

127. Rosado, J.A.; Meijer, E.M.; Hamulyak, K.; Novakova, I.; Heemskerk, J.W.; Sage, S.O. Fibrinogen binding to the integrin alpha(IIb)beta(3) modulates store-mediated calcium entry in human platelets. Blood 2001, 97, 2648-2656. [CrossRef]

128. Rosado, J.A.; Porras, T.; Conde, M.; Sage, S.O. Cyclic nucleotides modulate store-mediated calcium entry through the activation of protein-tyrosine phosphatases and altered actin polymerization in human platelets. J. Biol. Chem. 2001, 276, 15666-15675. [CrossRef]

129. Doni, M.G.; Cavallini, L.; Alexandre, A. Ca2+ influx in platelets: Activation by thrombin and by the depletion of the stores. Effect of cyclic nucleotides. Biochem. J. 1994, 303(Pt 2), 599-605. [CrossRef]

130. Nakamura, K.; Kimura, M.; Aviv, A. Role of cyclic nucleotides in store-mediated external $\mathrm{Ca}^{2+}$ entry in human platelets. Biochem. J. 1995, 310 (Pt 1), 263-269. [CrossRef]

131. Harbeck, B.; Hüttelmaier, S.; Schluter, K.; Jockusch, B.M.; Illenberger, S. Phosphorylation of the vasodilator-stimulated phosphoprotein regulates its interaction with actin. J. Biol. Chem. 2000, 275, 30817-30825. [CrossRef]

132. Bodnar, R.J.; Xi, X.; Li, Z.; Berndt, M.C.; Du, X. Regulation of glycoprotein Ib-IX-von Willebrand factor interaction by cAMP-dependent protein kinase-mediated phosphorylation at Ser 166 of glycoprotein Ib(beta). J. Biol. Chem. 2002, 277, 47080-47087. [CrossRef] [PubMed]

133. Quinton, T.M.; Dean, W.L. Cyclic AMP-dependent phosphorylation of the inositol-1,4,5-trisphosphate receptor inhibits Ca2+ release from platelet membranes. Biochem. Biophys. Res. Commun. 1992, 184, 893-899. [CrossRef] 
134. Peshavariya, H.M.; Liu, G.-S.; Chang, C.W.T.; Jiang, F.; Chan, E.C.; Dusting, G.J. Prostacyclin signaling boosts NADPH oxidase 4 in the endothelium promoting cytoprotection and angiogenesis. Antioxid. Redox Signal. 2014, 20, 2710-2725. [CrossRef] [PubMed]

135. Hoang, K.G.; Allison, S.; Murray, M.; Petrovic, N. Prostanoids regulate angiogenesis acting primarily on IP and EP4 receptors. Microvasc. Re.s 2015, 101, 127-134. [CrossRef]

136. Smith, J.B.; Silver, M.J.; Ingerman, C.M.; Kocsis, J.J. Prostaglandin D2 inhibits the aggregation of human platelets. Thromb. Res. 1974, 5, 291-299. [CrossRef]

137. Pluchart, H.; Khouri, C.; Blaise, S.; Roustit, M.; Cracowski, J.-L. Targeting the prostacyclin pathway: Beyond pulmonary arterial hypertension. Trends Pharmacol. Sci. 2017, 38, 512-523. [CrossRef]

138. Fox, C.J.; Cornett, E.M.; Hart, B.M.; Kaye, A.J.; Patil, S.S.; Turpin, M.C.; Valdez, A.; Urman, R.D.; Kaye, A.D. Pulmonary vasodilators: Latest evidence and outcomes in the perioperative setting. Best Pract. Res. Clin. Anaesthesiol. 2018, 32, 237-250. [CrossRef]

139. Salehi, A. Pulmonary hypertension: A review of pathophysiology and anesthetic management. Am. J. Ther. 2012, 19, 377-383. [CrossRef]

140. McLaughlin, V.V.; Archer, S.L.; Badesch, D.B.; Barst, R.J.; Farber, H.W.; Lindner, J.R.; Mathier, M.A.; McGoon, M.D.; Park, M.H.; Rosenson, R.S.; et al. ACCF/AHA 2009 expert consensus document on pulmonary hypertension: A report of the American College of Cardiology Foundation Task Force on Expert Consensus Documents and the American Heart Association: Developed in collaboration with the American College of Chest Physicians, American Thoracic Society, Inc., and the Pulmonary Hypertension Association. Circulation 2009, 119, 2250-2294. [CrossRef]

141. Hirsch, A.T.; Haskal, Z.J.; Hertzer, N.R.; Bakal, C.W.; Creager, M.A.; Halperin, J.L.; Hiratzka, L.F.; Murphy, W.R.C.; Olin, J.W.; Puschett, J.B.; et al. ACC/AHA 2005 Practice Guidelines for the management of patients with peripheral arterial disease (lower extremity, renal, mesenteric, and abdominal aortic): A collaborative report from the American Association for Vascular Surgery/Society for Vascular Surgery, Society for Cardiovascular Angiography and Interventions, Society for Vascular Medicine and Biology, Society of Interventional Radiology, and the ACC/AHA Task Force on Practice Guidelines (Writing Committee to Develop Guidelines for the Management of Patients With Peripheral Arterial Disease): Endorsed by the American Association of Cardiovascular and Pulmonary Rehabilitation; National Heart, Lung, and Blood Institute; Society for Vascular Nursing; TransAtlantic Inter-Society Consensus; and Vascular Disease Foundation. Circulation 2006, 113, e463-e654. [CrossRef]

142. The Oral Iloprost in Severe Leg Ischaemia Study Group. Two randomised and placebo-controlled studies of an oral prostacyclin analogue (Iloprost) in severe leg ischaemia. Eur. J. Vasc. Endovasc. Surg. 2000, 20, 358-362. [CrossRef] [PubMed]

143. Lau, K.E.; Lui, F. Physiology, prostaglandin I2. In StatPearls; StatPearls Publishing: Treasure Island, FL, USA, 2020.

144. Gaillard-Bigot, F.; Roustit, M.; Blaise, S.; Cracowski, C.; Seinturier, C.; Imbert, B.; Carpentier, P.; Cracowski, J.-L. Treprostinil iontophoresis improves digital blood flow during local cooling in systemic sclerosis. Microcirculation 2016, 23, 266-270. [CrossRef] [PubMed]

145. Giles, H.; Leff, P. The biology and pharmacology of PGD2. Prostaglandins 1988, 35, 277-300. [CrossRef]

146. Keery, R.J.; Lumley, P. AH6809, a prostaglandin DP-receptor blocking drug on human platelets. Br. J. Pharmacol. 1988, 94, 745-754. [CrossRef]

147. Fukushima, M. Prostaglandin J2-Anti-tumour and anti-viral activities and the mechanisms involved. Eicosanoids 1990, 3, 189-199.

148. Giles, H.; Leff, P.; Bolofo, M.L.; Kelly, M.G.; Robertson, A.D. The classification of prostaglandin DP-receptors in platelets and vasculature using BW A868C, a novel, selective and potent competitive antagonist. Br. J. Pharmacol. 1989, 96, 291-300. [CrossRef]

149. Schuligoi, R.; Schmidt, R.; Geisslinger, G.; Kollroser, M.; Peskar, B.A.; Heinemann, A. PGD2 metabolism in plasma: Kinetics and relationship with bioactivity on DP1 and CRTH2 receptors. Biochem. Pharmacol. 2007, 74, 107-117. [CrossRef]

150. Norman, P. Update on the status of DP2 receptor antagonists; from proof of concept through clinical failures to promising new drugs. Expert. Opin. Investig. Drugs 2014, 23, 55-66. [CrossRef]

151. Asano, K.; Sagara, H.; Ichinose, M.; Hirata, M.; Nakajima, A.; Ortega, H.; Tohda, Y. A phase 2a study of DP2 antagonist GB001 for asthma. J. Allergy Clin. Immunol. Pract. 2020, 8, 1275-1283.e1. [CrossRef] 
152. Marone, G.; Galdiero, M.R.; Pecoraro, A.; Pucino, V.; Criscuolo, G.; Triassi, M.; Varricchi, G. Prostaglandin D2 receptor antagonists in allergic disorders: Safety, efficacy, and future perspectives. Expert. Opin. Investig. Drugs 2019, 28, 73-84. [CrossRef]

153. Levin, G.; Duffin, K.L.; Obukowicz, M.G.; Hummert, S.L.; Fujiwara, H.; Needleman, P.; Raz, A. Differential metabolism of dihomo-gamma-linolenic acid and arachidonic acid by cyclo-oxygenase-1 and cyclo-oxygenase-2: Implications for cellular synthesis of prostaglandin E1 and prostaglandin E2. Biochem. J. 2002, 365, 489-496. [CrossRef] [PubMed]

154. Dutta-Roy, A.K.; Kahn, N.N.; Sinha, A.K. Prostaglandin E1: The endogenous physiological regulator of platelet mediated blood coagulation. Prostaglandins Leukot. Essent. Fat. Acids 1989, 35, 189-195. [CrossRef]

155. Koga, T.; Az-ma, T.; Yuge, O. Prostaglandin E1 at clinically relevant concentrations inhibits aggregation of platelets under synergic interaction with endothelial cells. Acta Anaesthesiol. Scand. 2002, 46, 987-993. [CrossRef] [PubMed]

156. Granström, E. On the metabolism of prostaglandin E1 in man: Prostaglandins and related factors. Prog. Biochem. Pharmacol. 1967, 3, 89-93.

157. Long, W.A.; Rubin, L.J. Prostacyclin and PGE1 treatment of pulmonary hypertension. Am. Rev. Respir. Dis. 1987, 136, 773-776. [CrossRef]

158. Anggård, E. The biological activities of three metabolites of prostaglandin E 1. Acta Physiol. Scand. 1966, 66, 509-510. [CrossRef] [PubMed]

159. Jap, T.S.; Kwok, C.F.; Wong, M.C.; Chiang, H. The effects of in vitro and in vivo exposure to insulin upon prostaglandin E1 stimulation of platelet adenylate cyclase activity in healthy subjects. Diabetes Res. 1994, 27, $39-46$.

160. Michel, H.; Caen, J.P.; Born, G.V.; Miller, R.; D'Auriac, G.A.; Meyer, P. Relation between the inhibition of aggregation and the concentration of cAMP in human and rat platelets. Br. J. Haematol. 1976, 33, 27-38. [CrossRef]

161. Kikura, M.; Kazama, T.; Ikeda, T.; Sato, S. Disaggregatory effects of prostaglandin E1, amrinone and milrinone on platelet aggregation in human whole blood. Platelets 2000, 11, 446-458. [CrossRef]

162. Schafer, A.I.; Cooper, B.; O'Hara, D.; Handin, R.I. Identification of platelet receptors for prostaglandin I2 and D2. J. Biol. Chem. 1979, 254, 2914-2917.

163. Kiriyama, M.; Ushikubi, F.; Kobayashi, T.; Hirata, M.; Sugimoto, Y.; Narumiya, S. Ligand binding specificities of the eight types and subtypes of the mouse prostanoid receptors expressed in Chinese hamster ovary cells. Br. J. Pharmacol. 1997, 122, 217-224. [CrossRef] [PubMed]

164. Iyú, D.; Jüttner, M.; Glenn, J.R.; White, A.E.; Johnson, A.J.; Fox, S.C.; Heptinstall, S. PGE1 and PGE2 modify platelet function through different prostanoid receptors. Prostaglandins Other Lipid Mediat. 2011, 94, 9-16. [CrossRef] [PubMed]

165. Ye, Z.; Lu, H.; Guo, W.; Dai, W.; Li, H.; Yang, H.; Li, L. The effect of alprostadil on preventing contrast-induced nephropathy for percutaneous coronary intervention in diabetic patients: A systematic review and meta-analysis. Medicine 2016, 95, e5306. [CrossRef]

166. Hatzimouratidis, K.; Salonia, A.; Adaikan, G.; Buvat, J.; Carrier, S.; El-Meliegy, A.; McCullough, A.; Torres, L.O.; Khera, M. Pharmacotherapy for erectile dysfunction: Recommendations from the fourth International Consultation for Sexual Medicine (ICSM 2015). J. Sex. Med. 2016, 13, 465-488. [CrossRef]

167. Vietto, V.; Franco, J.V.; Saenz, V.; Cytryn, D.; Chas, J.; Ciapponi, A. Prostanoids for critical limb ischaemia. Cochrane Database Syst. Rev. 2018, 1, CD006544. [CrossRef] [PubMed]

168. Kuriyama, S.; Kashiwagi, H.; Yuhki, K.; Kojima, F.; Yamada, T.; Fujino, T.; Hara, A.; Takayama, K.; Maruyama, T.; Yoshida, A.; et al. Selective activation of the prostaglandin E2 receptor subtype EP2 or EP4 leads to inhibition of platelet aggregation. Thromb. Haemost. 2010, 104, 796-803. [CrossRef] [PubMed]

169. Philipose, S.; Konya, V.; Sreckovic, I.; Marsche, G.; Lippe, I.T.; Peskar, B.A.; Heinemann, A.; Schuligoi, R. The prostaglandin E2 receptor EP4 is expressed by human platelets and potently inhibits platelet aggregation and thrombus formation. Arterioscler. Thromb. Vasc. Biol. 2010, 30, 2416-2423. [CrossRef]

170. Smith, J.B.; Willis, A.L. Aspirin selectively inhibits prostaglandin production in human platelets. Nat. New Biol. 1971, 231, 235-237. [CrossRef]

171. Schober, L.J.; Khandoga, A.L.; Dwivedi, S.; Penz, S.M.; Maruyama, T.; Brandl, R.; Siess, W. The role of PGE(2) in human atherosclerotic plaque on platelet $\mathrm{EP}(3)$ and $\mathrm{EP}(4)$ receptor activation and platelet function in whole blood. J. Thromb. Thrombolysis 2011, 32, 158-166. [CrossRef] 
172. Abramovitz, M.; Adam, M.; Boie, Y.; Carrière, M.; Denis, D.; Godbout, C.; Lamontagne, S.; Rochette, C.; Sawyer, N.; Tremblay, N.M.; et al. The utilization of recombinant prostanoid receptors to determine the affinities and selectivities of prostaglandins and related analogs. Biochim. Biophys. Acta 2000, 1483, 285-293. [CrossRef]

173. Sanchez-Ramos, L.; Peterson, D.E.; Delke, I.; Gaudier, F.L.; Kaunitz, A.M. Labor induction with prostaglandin E1 misoprostol compared with dinoprostone vaginal insert: A randomized trial. Obstet. Gynecol. 1998, 91, 401-405. [CrossRef]

174. Belfrage, P.; Smedvig, E.; Gjessing, L.; Eggebø, T.M.; Okland, I. A randomized prospective study of misoprostol and dinoproston for induction of labor. Acta Obstet. Gynecol. Scand. 2000, 79, 1065-1068. [PubMed]

175. Schmitz, G.; Ecker, J. The opposing effects of n-3 and n-6 fatty acids. Prog. Lipid Res. 2008, 47, 147-155. [CrossRef] [PubMed]

176. Yang, P.; Jiang, Y.; Fischer, S.M. Prostaglandin E3 metabolism and cancer. Cancer Lett. 2014, 348, 1-11. [CrossRef] [PubMed]

177. Szymczak, M.; Murray, M.; Petrovic, N. Modulation of angiogenesis by $\omega-3$ polyunsaturated fatty acids is mediated by cyclooxygenases. Blood 2008, 111, 3514-3521. [CrossRef]

178. Turco, S.D.; Basta, G.; Lazzerini, G.; Evangelista, M.; Rainaldi, G.; Tanganelli, P.; Camera, M.; Tremoli, E.; Caterina, R.D. Parallel decrease of tissue factor surface exposure and increase of tissue factor microparticle release by the n-3 fatty acid docosahexaenoate in endothelial cells. Thromb. Haemost. 2007, 98, 210-219. [CrossRef]

179. Madonna, R.; Salerni, S.; Schiavone, D.; Glatz, J.; Geng, Y.-J.; Caterin, R. Omega-3 fatty acids attenuate constitutive and insulin-induced CD36 expression through a suppression of PPAR $\alpha / \gamma$ activity in microvascular endothelial cells. Thromb. Haemost. 2011, 106, 500-510. [CrossRef]

180. Iyú, D.; Glenn, J.R.; White, A.E.; Johnson, A.; Heptinstall, S.; Fox, S.C. The role of prostanoid receptors in mediating the effects of PGE3 on human platelet function. Thromb. Haemost. 2012, 107, 797-799. [CrossRef]

181. Gryglewski, R.J.; Salmon, J.A.; Ubatuba, F.B.; Weatherly, B.C.; Moncada, S.; Vane, J.R. Effects of all cis-5,8,11,14,17 eicosapentaenoic acid and PGH3 on platelet aggregation. Prostaglandins 1979, 18, 453-478. [CrossRef]

182. Yeung, J.; Hawley, M.; Holinstat, M. The expansive role of oxylipins on platelet biology. J. Mol. Med. 2017, 95, 575-588. [CrossRef]

183. Gremmel, T.; Michelson, A.D.; Frelinger, A.L.; Bhatt, D.L. Novel aspects of antiplatelet therapy in cardiovascular disease. Res. Pract. Thromb. Haemost. 2018, 2, 439-449. [CrossRef] [PubMed]

184. Biringer, R.G. A review of prostanoid receptors: Expression, characterization, regulation, and mechanism of action. J. Cell Commun. Signal. 2020. [CrossRef] [PubMed]

185. Ross, R. The pathogenesis of atherosclerosis: A perspective for the 1990s. Nature 1993, 362, 801-809. [CrossRef] [PubMed]

186. Lozano, R.; Naghavi, M.; Foreman, K.; Lim, S.; Shibuya, K.; Aboyans, V.; Abraham, J.; Adair, T.; Aggarwal, R.; Ahn, S.Y.; et al. Global and regional mortality from 235 causes of death for 20 age groups in 1990 and 2010: A systematic analysis for the Global Burden of Disease Study 2010. Lancet 2012, 380, 2095-2128. [CrossRef]

187. Smolenski, A. Novel roles of cAMP/cGMP-dependent signaling in platelets. J. Thromb. Haemost. 2012, 10, 167-176. [CrossRef]

188. Fabre, J.E.; Nguyen, M.; Athirakul, K.; Coggins, K.; McNeish, J.D.; Austin, S.; Parise, L.K.; FitzGerald, G.A.; Coffman, T.M.; Koller, B.H. Activation of the murine EP3 receptor for PGE2 inhibits cAMP production and promotes platelet aggregation. J. Clin. Invest. 2001, 107, 603-610. [CrossRef]

189. Heptinstall, S.; Espinosa, D.I.; Manolopoulos, P.; Glenn, J.R.; White, A.E.; Johnson, A.; Dovlatova, N.; Fox, S.C.; May, J.A.; Hermann, D.; et al. DG-041 inhibits the EP3 prostanoid receptor-A new target for inhibition of platelet function in atherothrombotic disease. Platelets 2008, 19, 605-613. [CrossRef]

Publisher's Note: MDPI stays neutral with regard to jurisdictional claims in published maps and institutional affiliations. 